Araştırma Makalesi

Research Article

\title{
Strateji Kavramını Çalışmak
}

\author{
Studying the Concept of Strategy
}

\author{
Hasan YÜKSELEN*
}

Güvenlik

Stratejileri

Y1l: 14

Sayı: 27

$\ddot{O}_{\mathbf{z}}$

Strateji askerî alanda ortaya çıkmasına ră̆men zaman içerisinde genişleyerek birçok alanda uzun erimli ve yaşamsal konuların incelenmesinde kullanılan bir kavram haline gelmiştir. Ancak pozitivizmin etkisi altında aslında sosyal olan strateji giderek içinde bulunduğu bağlamdan koparlarak şeyleştirilmiş ve sadece elde mevcut olan araçlara indirgenerek öznesel nitelikleri göz ardı edilmiştir. Bu makalenin amacı, stratejiyi ne oluşturmakta ve mümkün kılmaktadır sorusundan hareketle stratejinin nasıl çalışılması gerektiği sorusuna tarihsel ve sosyolojik analizini mümkün kalabilecek bir yaklaşımı sunmaktır. Bunu yaparken de stratejinin tarihsel ve sosyolojik bir açıklamasını özne-yapı diyalektiği çerçevesinde eleştirel gerçekçilik olarak adlandırılan bilim felsefesinden faydalanarak açıklamaktadır.

Anahtar Kelimeler: Strateji, Praxis, Eleştirel Gerçekçilik, Ontolojik Derinlik, Özne-Yapı Diyalektiği.

\begin{abstract}
Despite emerging within military realm, the concept of strategy, in time, has broadened and has been begun to use in analysis of long-term and vital issues. However, with the effect of positivism, the concept of strategy, which is originally social in nature, has eventually been reified through disconnection from its context, and reduced through disregarding agential aspects but focusing primarily on means. The aim of this article is to seek an answer to the question of how strategy should be studied, based on the constituent questions of what makes strategy and what makes strategy possible, in order to suggest a historical and sociological explanation. To reach this explanation, the historical and

\footnotetext{
* Dr.Hv.İsth.Yb., NATO İstihbarat Füzyon Merkezi, RAF Molesworth, İngiltere,
} e-posta: hasanyukselen@hotmail.com.

Geliș Tarihi/Received: 14.03.2018 Kabul Tarihi/Accepted: 30.04.2018
\end{abstract}


sociological of strategy is sought by employing dialectical agent-structure approach from a differing philosophy of science stance named as critical realism.

Güvenlik Stratejileri

Y11: 14

Say1: 27
Keywords: Strategy, Praxis, Critical Realism, Ontological Depth, Agent-Structure Dialectics.

\section{Giriş}

Strateji kavramı, genel olarak askerî araçların politik amaçlar için kullanılması olarak tanımlana gelmiştir. ${ }^{1}$ Ancak kavramın çekiciliği zamanla birçok alanda kendisine alan açmasına ve daha da önemlisi girdiği alanlardaki karmaşık ve üst düzey konuların incelenmesinde kullanılan bir kavram halini almasına neden olmuştur. Diğer bir ifadeyle, askerî alanda ortaya çıkan "generalin sanatı" (strata geos) şeklindeki bir tanımlamadan uzaklaşarak, zaman içerisinde daha geniş, kapsayıcı ve askerî alanın dışında daha yoğun çalışılan bir kavram haline dönüşmüştür. $\mathrm{Bu}$ genişleme kavramın muğlaklaşması ve bu muğlaklaşmanın sonucunda da analitik bütünlüğün bozulması tartışmasını ortaya çıkarsa da, aslında ortaya çıkan tartışmalar, kavramın felsefi arka planı ve farklı disiplinlerde çalışılması tartışmaların derinleşmesini de beraberinde getirmiştir. Esasen, güvenlik kavramı nasıl bir genişleme ve derinleşme $e^{2}$ ile karşılaştıysa, aslında onun temel kavramlarından olan strateji kavramı da aynı kaderi paylaşmış ve giderek daha fazla derinleşmiş ve genişlemiştir.

Genişleme ve derinleşme, strateji kavramının bu süreçten faydalanarak daha kapsamlı ve derinlemesine çalışılmasını beraberinde getirse de, aslında bilim felsefesindeki gelişmelerin kavramın çalışılmasına yansıtılmadığı için beklenen derinleşmenin strateji

${ }^{1}$ Beatrice Heuser, The Evolution of Strategy: Thinking War from Antiquity to the Present, Cambridge University Press, Cambridge, 2010; Peter Paret, Gordon A.Craig ve Felix Gilbert, Makers of Modern Strategy: From Machiavelli to the Nuclear Age, Princeton University Press, Princeton, 1986.

${ }^{2}$ Barry Buzan, People, States and Fear: An Agenda for International Security Studies in the Post-Cold War Era, ECPR, Colchester, 2007; Barry Buzan, Ole Weaver ve Jaap de Wilde, Security: A New Framework for Analysis, Lynne Rienner, Colorado, 1998. 
kavramının çalışılmasında karşılık bulmadığı iddia edilebilir. $\mathrm{Bu}$ durumun kavramın doğasından kaynaklanan çeşitli nedenleri olmakla birlikte, aslında Batı felsefesinde pozitivizmin sahip olduğu birincil rol, kavramın temel olarak kaynaklarla da ilgili olmasindan dolay1 materyalist ve kapitalist odağının ön planda durması da bu nedenler arasında sayılabilir. ${ }^{3}$ Diğer bir ifadeyle, mevcut ana akım teorilerin, biraz da kapitalist, materyalist ve pozitivist Batı felsefesinin etkisiyle strateji kavramının çalışılması, barındırdığ 1 amaçlardan sıyrılarak sadece var olan araçlara indirgenmesi ile karşı karşıya kalmıştır. Bu noktada, amaçlar göz ardı edilirken araçlara odaklanılmış; kısaca indirgemeci bir yaklaşım kavramın çalışılmasına hâkim olmuştur. Ancak strateji kavramı araçları kapsasa da, amaçların olmadığı bir ortamda bir şekilde öznellikten uzaklaştırılarak materyalize edilmektedir. $\mathrm{Bu}$ durumda stratejinin düşünceden eyleme dönüştüğü sürecin asıl öğesi olan özne süreçten koparılmakta; strateji böylelikle şeyleştirilmektedir. Hâlbuki strateji kavramı, temelde, araçların amaçlara koşulduğu sosyal ve öznel bir kavramdır.

Strateji kavramının yukarıda ifade edildiği gibi araçlara indirgenmesi, öznenin kavramın özünden koparılması ya da yok sayılması sonucunu ortaya çıkarmıştır. Öznenin yok sayılmasında pozitivizmin özne-nesne, değer-olgu gibi karşıtlıkları temel almasının doğrudan etkisi olmuştur. Ancak bu süreçte öznenin şeyleştirilmesi ve stratejinin sadece sahip olunan materyal kapasiteye indirgenmesi, strateji kavramının çalışılmasında, öznenin de temelde öznesel olan strateji sürecinden koparılmasını beraberinde getirmiştir. Ken Booth'un Adorno'dan esinlenerek ifade ettiği gibi, "her şeyleştirme bir unutuluştur" ve bir siyasal seçim olarak Cox'un "her unutuluş birisi ve bir amaç içindir" ifadeleri, düşünümsellik ve farkındalık gibi ayırt edici

\footnotetext{
${ }^{3}$ Richard Wyn Jones, Security, Strategy and Critical Theory, Lynne Rienner, Colorado, 1999.

${ }^{4}$ Ken Booth, Theory of World Security, Cambridge University Press, Cambridge, 2007, s. 185.

${ }^{5}$ Robert Cox, "Social Forces, States and World Orders: Beyond International Relations
}

Güvenlik Stratejileri

Y11: 14

Sayı: 27 
nitelikleriyle ontolojik bir varlık olarak öznenin stratejiden koparılmasını da beraberinde getirmiştir. Göz ardı edilmesine rağmen, özne neden

Güvenlik Stratejileri

Y11: 14

Say1: 27 önemli sorusunun cevabı, strateji kavramının kaynaklardan öte düşünsel ve eylemsel bir boyutunun olmasından kaynaklanmaktadır. Zira stratejiyi gereksinim duyan da, oluşturan da, araçları amaçlara koşan da öznedir. Stratejinin düşünsel boyutunu oluşturan öznenin göz ardı edilmesi kaçınılmaz olarak indirgemeciliği de beraberinde getirmektedir. $\mathrm{Bu}$ noktadan hareketle, bu makalenin yazılmasındaki temel amaç, pozitivizmin etkisiyle indirgemeci ve şeyleştirilmiş bir bakış açısıyla çalışılan strateji kavramının öznesel yönünü ön plana çıkaracak bir yaklaşımı ortaya koymaktır. Seçim yapma yetisiyle, amaçların belirleyicisi olan öznenin sürece tekrar dâhil edilmesi amacıyla, bu makalede strateji kavramının özne-yapı diyalektiği çerçevesinde çalışılması gerektiği iddia edilecektir. Kısacası, araçlara indirgenerek çalışılan bir kavramı bu makale, amaçları da sürece katan bir yaklaşım ile özneyi yeniden gündeme getiren bir duruş benimsemektedir.

$\mathrm{Bu}$ çerçevede, bu makalenin cevabını aradığ 1 soru "stratejiyi ne oluşturmakta" ve mümkün kılmaktadır şeklinde belirlenmiştir. $\mathrm{Bu}$ doğrultuda amaç, stratejiyi oluşturan ve mümkün kılan etmenlerin ve nedensel mekanizmaların neler olduğunu açıklamak olacaktır. Makalenin temel iddias1, stratejinin temel olarak özneye ait, özne olma ile ilgili bir kavram olması kabulünden yola çıkarak tarihsel ve sosyolojik bir kavram olarak analiz edilmesi gerektiği; bu nedenle de öznenin yapıyla etkileşimini ortaya koyabilecek şekilde kavramın özne-yapı diyalektiği içerisinde ve eleştirel gerçekçilik bakış açısıyla çalışılması gerektiğidir. Bilim felsefesi olarak ontolojiyi ve ontolojik derinlik kavramını ön plana çıkaran eleştirel gerçekçiliğin, yöntemsel olarak kavramın sosyolojik ve tarihsel bir analizini mümkün kılan diyalektik düşüncenin, strateji kavramına daha kapsamlı bir açıklama sunduğu iddia edilecektir. Kısacası, bu makalede stratejinin pasif ve türevsel kavramsallaştırmalarının ötesinde aktif, bilinçli ve inovatif bir

Theory", Millennium: Journal of International Studies, Cilt 10, Sayı 2, 126-155, s. 128. 
kavramsallaştırmasının temelleri ortaya koyulacaktır.

$\mathrm{Bu}$ tartı̧̧manın yapılabilmesi için, öncelikle strateji kavramının mevcut literatürde ne şekilde ele alındığı konusu eksiklikleri ile ortaya koyulacaktır. Tespit edilen eksikliklerin nereden kaynaklandığı tartı̧̧ıldıktan sonra, eleştirel gerçekçi bir bakış açısıyla yöntem olarak özne-yap1 diyalektiğinin strateji kavramının çalışılmasına katkıları tartışılacaktır. Strateji çalışmaları pozitivizmin etkisiyle strateji kavramını bir analiz kategorisi olarak ele almaktadır. Ancak stratejiye bir öznel eylem-praxis kategorisi olarak yaklaşmak, kavramın daha kapsamlı çalışılmasına imkân vermektedir. Stratejiyi "öznel eylem" olarak gören yaklaşımlar, yeni olamamakla birlikte, bu konuya eleştirel gerçekçilik çerçevesinde yaklaşım aslında kavramın çalışılmasında yeni açılımlar sağlamaktadır. Eleştirel gerçekçiliğin bir bilim felsefesi olması nedeniyle pozitivist felsefe üzerine kurulan teorilerin ötesinde ontolojiyi ön plana çıkararak kavramın sosyolojik ve tarihsel temelde çalışılmasına imkân vermektedir. Diyalektik ise pozitivizmin parça ve bütünü yapay önceliklendirilmesini aşmada bir yöntem olarak düşünülmektedir. ${ }^{6}$ Son bölümde ise, strateji kavramının çalışılmasına ilişkin bir yaklaşımın ana noktaları ortaya koyulacaktır.

\section{Strateji Kavramını Çalışmayı Sorgulamak: Kavram, Yaklaşım, Eleştiri}

Strateji kavramının çeşitli tanımlamaları yapılmaktadır. Clausewitz, stratejiyi "muharebelerin savaşın amacı için kullanılması"” ş̧eklinde tanımlarken; benzer şekilde Basil Liddell Hart da, stratejiyi "askerî araçların siyasetin amaçları doğrultusunda dağıtılması ve uygulanması sanatı" olarak; Gregory Foster ise stratejiyi "en nihayetinde etkili güç

\footnotetext{
${ }^{6}$ Christian Heine ve Benno Teschke, "Sleeping Beauty and Dialectical Awakening: On the Potential of Dialectic for International Relations", Millennium: Journal of International Studies, Cilt 25, Say1 2, 1996, 399-423, s. 417.

${ }^{7}$ Carl Von Clausewitz, On War, (çev.Michael Howard ve Peter Paret), Princeton University Press, Princeton, 1976, s. 177.

${ }^{8}$ Basil Liddell Hart, Strategy, Faber, London, 1967, s. 335.
}

Güvenlik Stratejileri

Y11: 14

Say1: 27 
kullanmak" olarak görmüştür. Colin S. Gray, stratejiyi "organize gücün siyasal amaçlar için kullanımı ve niyetinin teori ve pratiği" 10

Güvenlik Stratejileri

Y11: 14

Sayl: 27 olarak tanımlamıştır. Bu tanımlara her ne kadar amaçlar ve araçlar dâhil edilse de, bir şekilde askerî araçlar temelli gücün siyasi olan bir amaç doğrultusunda kullanılması ön plana çıkarılmış, buna karşılık amaçların çeşitliliği ikinci plana itilmiştir. W. Murray ve M.Grimsley ise stratejiyi "şans ve belirsizliğin hâkim olduğu bir dünyadaki değişen koşullara ve şartlara sürekli uyumu içeren bir süreç" ${ }^{11}$ olarak tanımlayarak stratejinin uyumsal ve süreçsel özelliklerini ön plana çıkarmıştır. André Beufre ise stratejiyi "sorunu çözmek amacıyla güç kullanan iki kuvvetin diyalektiği ya da tam olarak iki karşıt iradenin diyalektiği’"12 olarak tanımlayarak stratejinin hem kendi içerisinde, hem de iki özne arasındaki diyalektik niteliğine vurgu yapmıştır.

Tanımlamalardaki farklılıklar teorisyenlerin kuramsal ve felsefi bakış açılarının kavramın çalışılmasına olan yansımalarından kaynaklanırken, alaylı olarak tabir edebileceğimiz uygulayıcıların tanımlamalarındaki farklılıklar, daha çok harekât alanında yaşayarak edindikleri tecrübelerin farklılaşmasından kaynaklanmıştır. Kısacası, gerek teorisyenlerin gerekse alaylıların yaşadıkları tarihsel ve sosyolojik dönemler, kavramın incelenmesinde olduğu gibi, yaptıkları tanımlamalarda da kendisini göstermiştir. ${ }^{13}$ Diğer taraftan da, farklılıklar aslında strateji kavramının tanımının yapılmasının ne kadar zor olduğunu

${ }^{9}$ Gregory Foster, "Research, Writing and the Mind of the Strategist", Joint Force Quarterly, Say1 14, 1996, 111-115, s. 111.

${ }^{10}$ Colin S. Gray, Modern Strategy, Oxford University Press, Oxford, 1999, s. 1.

${ }^{11}$ Williamson Murray ve Mark Grimsley, "Introduction: On Strategy", Williamson Murray, MacGregor Knox ve Alvin Bertsein (der.) The Making of Strategy: Rulers, States, and War, Cambridge University Press, Cambridge, 1994, 1-24, s. 1.

${ }^{12}$ André Baufre, An Introduction to Strategy: With Particular Reference to the Problems of Defence, Politics, Economics, and Diplomacy in the Nuclear Age, Faber \& Faber, London, 1965, s. 22.

${ }^{13}$ Stratejinin bağlamsal doğasına önem veren bir yaklaşım için bkz. Philip Windsor, "The Clock, the Context and Clausewitz", Millennium: Journal of International Studies, Sayı 6, Cilt 2, 190-196. 
da göstermektedir. Fakat bu farklılıklar, üzerinde uzlaşılan noktaların ve birtakım genellemelerin çıkmasını da engellememiştir. Diğer yandan, farklılıklara rağmen stratejinin özünde değişmediğini sadece uygulamalarının ve araçlarının değiştiği vurgulanmaktadır. ${ }^{14} \mathrm{Bu}$ iddianın temelinde de insanın doğasında var olan "korku, onur ve çıar" 15 kavramlarının sürekliliği gösterilmektedir.

Tanımlardaki ortak özelliklere baktığımızda, temel olarak strateji kavramının ana unsurları olarak "araçları ve amaçları" saymak mümkündür. Dahası, bu araçlar ile amaçların uyumlandırılması bir süreci gerektirmektedir. ${ }^{16}$ Ancak Bernard Brodie "Bir Bilim olarak Strateji" adlı yazısında stratejiyi "uygulamalı bilim" olarak gördügünden dolayı, bilimsel olarak çalışılması gerektiğini iddia etmiştir. ${ }^{17}$ Brodie, stratejinin eylemsel ve faydacı doğasına vurgu yaparak "stratejik teori, eylemin teorisidir" demiştir. ${ }^{18} \mathrm{Bu}$ yaklaşımın temelinde stratejinin politik sorunları çözmeyi amaçlayan araçsal doğası yatmaktadır. Kısacası, pozitivizmin etkisi altında özünde diyalektik yönüyle sosyal olan kavrama, bilimsellik katmak adına pozitif olarak ölçülebilecek araçlara odaklanılmıştır. Bu şekilde, bir araçsallaştırmanın sonucu ise amaçların araçlara indirgenmesi olmuştur. Bunun asıl önemli sonucu ise, strateji kavramının araçları oluşturan ana unsur olan sayılabilir nitelikteki materyal güce indirgenmesi olmuştur. ${ }^{19}$ Fakat Clausewitz'e benzer şekilde, Aron, siyasi çıkarların ve dolayısıyla amaçların değişken ve çeşitli olabileceğini ve güç isteğine indirgenemeyeceğini savunmuştur. ${ }^{20}$

\footnotetext{
${ }^{14}$ Colin S. Gray, The Future of Strategy, Polity Press, Cambridge, 2015, s. 63-79.

${ }^{15}$ Thucydides, The Landmark Thucydides: A Comprehensive Guide to "The Peloponnesian War”, Robert B. Strassler (der.), Richard Crawley (çev), The Free Press, New York, 1996, s. 43.

${ }^{16}$ Colin S. Gray, op cit, s. 24-28.

${ }^{17}$ Bernard Brodie, "Strategy as a Science", World Politics, Cilt 1, Sayl 4, 1949, 467-488.

${ }^{18}$ Bernard Brodie, War and Politics, Cassell, London, 1974, s. 452.

${ }^{19}$ Wyn Jones, op cit, s. 128-134.

20 Muriell Cozette, "Realistic Realism?: American Political Realism, Clausewitz and Raymond Aron on the Problem of Means and Ends in International Politics", Journal of
}

Güvenlik Stratejileri

Y11: 14

Say1: 27 
$\mathrm{Bu}$ noktada, Foucault'nun güç-bilgi ilişkisine de değinmekte

Güvenlik

Stratejileri

Y1l: 14

Say1: 27 fayda görülmektedir. Foucault, bir kavramın çalışılması sürecinin -bir şeyin bilgisinin üretilmesi- zaman içerisinde o kavramın konuşulması ile ilgili kuralları ürettiğini ve sonrasında, aslında Cox'un çözümsel teorilerde $^{21}$ vurguladığı özelliklere benzer şekilde, bir kavramın çalışılmasını mümkün kılan ve sınırlayan yapıların oluştuğunu iddia etmektedir. ${ }^{22}$ Bir kez oluştuğunda, bu yapılar, o kavramın çalışılma şeklini, nihayetinde de meşruluk atfederek bilgi üretme şeklini belirlemeye başlamaktadır. ${ }^{23}$ Tabi burada dikkat edilmesi gereken nokta, Foucault'da güç kavramına atfedilen anlam ile strateji kavramının çalışılmasında güce atfedilen anlamın birbirinden etkileri bakımdan farklılık göstermesidir. Foucault'nun çalışmalarının asıl katkısı, pozitivizmin nasıl bilgi üretme yöntemini sınırladığını göstermesidir.

Fakat merkezine askerî gücü alan güç kavramı, strateji kavramını da sayısal nicelikleri ve teknolojik nitelikleri hesaba katan bir çalışma alanına dönüştürmüştür. Stratejiyi askerî güç çerçevesinde ele almak entelektüel tutarl11ık ve bütünlüğün esası olarak da düşünülmüştür. ${ }^{24}$ Aksi takdirde, strateji çalışmalarının sınırları belirli bir alandan uzaklaşması durumunda bilimsellikten uzaklaşacağı korkusu hâkim olmuştur. Kısacası, teorisyenler stratejinin çalışılmasında bilimselliğe ulaşmak adına sınırları

Strategic Studies, Cilt 27, Sayl 3, 2010, 423-458, s. 440.

${ }^{21}$ Robert Cox, op cit, s.128-129.

${ }^{22}$ Michel Foucault, The Archeology of Knowledge, Routledge, Oxon, 2008; Michel Foucault, The History of Sexuality: The Will to Knowledge, Penguin, London, 1998; Eleştirel Gerçekçi bir okuması için bkz. Jonathan Joseph, "Foucault and Reality", Capital \& Class, Cilt 82, 2004, s. 141-163.

${ }^{23}$ Richard K. Ashley and R.B.J. Walker, "Speaking the Languages of Exile: Dissident Thought in International Studies", International Studies Quarterly, Cilt 34, Sayı 3, 1990, 259-268, s. 261. Ashley ve Walker, gücün olumsuz ve baskılayıcı değil, olumlu ve üretken olduğunu iddia ederek nasıl güç sahibinin istediği bilginin üretimini meşrulaştırdığını iddia ederek Foulcault'yu takip eder.

${ }^{24}$ Wyn Jones, op cit, s. 127. Entelektüel tutarlılık kavramı Buzan'ın güvenliğin genişlemesine ve derinleşmesine yönelik iddialarına karşın Stephen Walt'un yönelttiği bir eleştiridir. Bkz. Stephen Walt, "Renaissance of Security Studies", International Studies Quarterly, Cilt 35, Say1 2, 1991, 211-239. 
belirlenmiş bir çalışma konusu ve bu konunun çalışılmasında uygun yöntemin belirlenmesine odaklanmış ve buna sadık kalmaya çalışmaktadır. Tabi böyle bir anlayışın aşağıda daha ayrıntılı ele alınacak sosyal bir kavramı nasıl materyalize ettiğini de göstermektedir.

Çalışma alanı konusunu biraz daha netleştirmek adına strateji çalışmalarının nerede durduğuna da değinmekte fayda görülmektedir. Strateji ortaya çıkışı itibariyle "savaş çalışmaları", daha geniş fakat güç odaklı yaklaşımlara eleştirel yaklaşan teorileri de içeren "güvenlik çalışmaları", savaşı daha geniş bir bağlamda inceleyen "uluslararası ilişkilerin" altında yer almaktadır. Kısacası, kavramın çalışıldığı bağlam genişledikçe, eleştirel yaklaşımlar da kendisine zemin bulmaktadır. Strateji kavramını bu şekilde uluslararası ilişkiler disiplinin bir alt alanı olarak kabul ettiğimizde; kavramın disiplin içerisinde nasıl ele alındığ 1 noktasında, uluslararası ilişkiler teorilerinin stratejinin çalışılmasında benimsediği yaklaşımların da üzerinde durulmalıdır. Bu şekilde konuyu daha bütünsel incelemenin yanı sıra, kuramsal farklılıklar ve benzerlikler ortaya koyulabilecektir.

Strateji kavramı uluslararası ilişkiler disiplininin ana akım teorisi olarak kabul edilen realizm çerçevesinde analiz edilegelmiştir. $\mathrm{Bu}$ eğilimde realizmin uluslararası ilişkilerin anarşik doğasına ve bu anarşi içerisinde hayatta kalmanın (survival) sahip olunan güç ile doğru orantılı olmasına atfettiği önem belirleyici olmuştur. ${ }^{25}$ Devletlerin arasındaki güç birikiminin savaşı ortaya çıkarabileceği ve savaşlarda sahip olunan gücün ne gibi siyasi sonuçlar doğurabileceği soruları temel inceleme konusu haline gelmiştir. ${ }^{26}$ Kisacası, realizm konuyu çıkar ve güç kavramlarına indirgemektedir. Bu tanımlamada çıkar

\footnotetext{
${ }^{25}$ John Baylis, James J.Wirtz ve Colin S.Gray, Strategy in the Contemporary World, 5 'inci Basim, Oxford University Press, Oxford, 2016, s. 6.

${ }^{26}$ Kenneth Waltz, Uluslararası sistemdeki güç dağılımındaki ani değişimlerin savaşların sebebi olduğunu iddia etmiştir. Yapısal Gerçekçilik olarak uluslararası ilişkiler literatüründe yer bulan bu yaklaşım, açıklamayı yapıda aramakla birlikte yapının ne olduğunu açıklamamaktadır. Kenneth Waltz, Theory of International Politics, Addison-Wesley Publishing Company, Reading, 1979.
} 
10

Güvenlik

Stratejileri

Y11: 14

Say1: 27

stratejinin amaçlarına; güç ise bu amaçlar için kullanılabilecek araçlara karşılık gelmektedir. Pozitivizmin sosyal bilimlerde yarattığ 1 etki neticesinde genel geçer düzenliliklerin tespit edilmesi ile ulaşılan genellemeler teorinin temel amacı kabul edilmiş; sonucunda da sade teoriler kurma girişimi kaçınılmaz olarak strateji gibi temelde öznesel ve öznesel olduğu için de sosyal bir kavramı güç ve çıkar gibi iki kavrama indirgemiştir. Bu indirgemecilik daha da ileriye giderek amaçların sadece araçlardaki niceliksel artş̧la değişebileceğini iddia etmektedir. Sonuçta, stratejideki değişim ise koşulabilecek güç miktarındaki değişime indirgenmektedir. Realizmin kendi eksikliklerini gidermek için ortaya çıkan sürümleri (yapısal, saldırgan realizm, savunmacı realizm ve neoklasik realizm) ise açıklamayı ya sistem düzeyindeki güç dağılımında ya da aktör düzeyindeki güç birikiminde aramıştır. Ancak güç odaklı yaklaşım stratejinin merkezinde kalmaya devam etmiştir.

Güç-fili (powerphiles) yaklaşımların strateji çalışmalarındaki egemenliğine karşın, güç-fobi (powerphobes) yaklaşımların ortaya koyduğu eleştiriler kavramın zaman içerisinde genişlemesini de beraberinde getirmiștir. Özellikle strateji kavramının askerî boyutunun egemen olduğu kavramsallaştırmalardan uzak durulmaya çalışılmaktadır. $\mathrm{Bu}$ ayrışmanın temelinde bu tip tanımlamaların savaşın ortadan kaldırılmasına katkı sağlamaktan ziyade, meşrulaştırılmasına zemin hazırladığ 1 ve bu şekilde savaşı ortaya çıkaran yapıların yeniden üretildiği iddiası yatmaktadır. ${ }^{27} \mathrm{Bu}$ yeniden üretimin temelinde, aşağıda daha detaylı tartışılacak olan strateji oluşturma sürecinde, araçsal rasyonalitenin hâkimiyeti neticesinde stratejiyi araçsal olarak görme ve temelde "seçim yapmayı ihtiva eden siyaset" anlayışından uzaklaşarak pozitivizmin özne/nesne, olgu/değer arasında oluşturduğu kesin ayrım neticesinde ürettiği bilinç yanılsaması yatmaktadır. ${ }^{28}$

Bunun yanında, realizmin "güç" temelli açıklamalarının yanı sıra; liberalizm "seçim" temelli açıklamalar geliştirerek devletlerin

${ }^{27}$ Baylis, Wirtz ve Gray, op cit, s. 9-12.

${ }^{28}$ Wyn Jones, op cit, s. 76. 
yeknesak bir yapıda olmadığını, sistem düzeyinde de karşılıklı bağımlılıkların, ${ }^{29}$ demokrasinin, ${ }^{30}$ uluslararası organizasyonların ${ }^{31}$ ve normları $^{32}$ savaşı ortadan kaldırmasa da kısıtladığını iddia etmektedir. Doğrudan stratejinin askerî boyutuna ilişkin açıklamalardan ziyade stratejinin politik amaçlarına odaklanan bir açıklama arayışına dikkatleri çeviren liberaller, daha ziyade askerî gücün politik amaçlar için kullanılmasının ötesinde daha çok büyük strateji (grand strategy) ve dış politika tartışmalarına odaklanmaktadır. ${ }^{33}$ Analiz düzeyi perspektifinden bakıldığında, liberaller yeknesak bir devlet yapısından ziyade, farklı çıkar gruplarının devletin dış politika tercihlerinde ne şekilde bir gerçeklik oluşturduğuna odaklanmaktadır. Kısacası, liberaller için, savaş ya da çatışma devlet içerisinde farklı gruplar arasında devam etmekte; sistem düzeyinde ise diplomasi diğer devletlerle olan sorunları çözmede araç olarak kullanılmaktadır. Dahası, liberaller stratejiyi askerî gücün siyasal amaçlar için kullanılması seçeneğini ya da denklemini aşmaya çalışmaktadır. Kısacası, güç kullanma bir seçenek olarak irdelenmekte ve siyasetin güdümünde olması gerektiği düşünülmektedir. Liberalizmin kavramın çalışılmasına katkısı, stratejinin de bir seçim olduğundan hareketle, öznenin sürece dâhil edilmesini gerekli görmesidir.

\footnotetext{
${ }^{29}$ Robert O Keohane ve Joseph S. Nye, Power and Interdependence: World Politics in Transition, Little \&Brown, Boston, 1989.

${ }^{30}$ Bu noktada Kant'ın "Ebedi Barış" yaklaşımı devletler arasında ticaretin geliştirilmesi ve demokratik ilkelerin benimsenmesi yoluyla realizmin temelini oluşturan ve Machiavelli ile Hobbes tarafindan ortaya atılan dünya görüşünün aksine devletlerin barışı tesis edebileceklerini iddia etmektedir. H.S. Reiss (ed.), Kant: Political Writings, Cambridge University Press, Cambridge, 1991, s. 116-124; Michael W. Doyle, "Kant, Liberal Legacies, and Foreign Affairs, Part 1 \& 2," Philosophy \& Public Affairs, Cilt 12, Sayı 3, 1983, 205-35; Joe D.Hagan, "Domestic Political Systems and War Proneness", Mershon International Studies Review, Cilt 38, 1994, 183-207.

${ }^{31}$ David L. Rousseau, Democracy and War: Institutions, Norms, and the Evolution of International Conflict, Stanford University Press, Stanford, 2005.

${ }^{32}$ Martha Finnemore ve Kathyrn Sikkink, "International Norm Dynamics and Political Change", International Organization, Cilt 52, Say1 2, 1998, 887-917.

${ }^{33}$ Richard Rosecrance ve Arthur A. Stein, The Domestic Bases of Grand Strategy, Cornell University Press, Ithaca ve Londra, 1993.
} 
12 Bu şekilde, realizmde yok sayılan amaçlar, strateji oluşturma sürecine

Güvenlik Stratejileri

Y11: 14

Say1: 27 dâhil edilmekte; ancak düzlemsel bir ontoloji ve katı bir özne/nesne ayrımını benimsediğinden bu sefer de araçları göz ardı ederek indirgemecilik ile karşı karşıya kalmaktadır.

İnşacı yaklaşım ise, bir teori olmanın ötesinde bir yaklaşım olarak, bir yandan strateji kavramının realist okumasının eleştirisinde kullanılmakta; bir yandan "özneler arası etkileşimin" savaşı/barış1 nası1 ortaya çıkardığını irdelemekte; diğer yandan da realist ve güç odaklı okumanın savaşı ortaya çıkaran yapının "sosyal inşa" yoluyla nasıl yeniden üretildiğini tartışmaktadır. Ancak stratejinin çalışılmasında özneyapı etkileşimini diyalektik olarak açıklamakta geri kalmaktadır. ${ }^{34}$ Bunda da özneler-arası bir ontolojik tercih temelinde bu özneler-arası olanın bilgi ve kimlik tarafindan üretilen ve inşa edilen öznel bir ontolojisi olduğu iddia edilmektedir. Dolayısıyla, öznel bir ontolojik gerçekliğin nesnel bilgisini elde etmeye çalışan epistemolojik bir yaklaşım benimsenmektedir. ${ }^{35}$ Ancak inşacılar ontolojik ve epistemolojik tercihlerinin birbirleriyle uyumlu olmadığı iddiasıyla eleştirilmektedir. ${ }^{36}$

Bunun yanında, inşacılık, öznenin kimlik inşası olgusundan yola çıkarak, stratejinin belirlenmesinde "stratejik kültür" odaklı eleştirilere de temel oluşturmaktadır. Burada özellikle araçlar kadar amaçların da nasıl şekillendiği ve strateji oluşturmada öznesel etkilerin neler olabileceği soruları belirleyici olmuştur. Strateji kavramının daha geniş olan güvenlik çalışmaları ve uluslararası ilişkiler bağlamında çalışılması eleştirel yaklaşımlara daha fazla alan açmış; böylelikle kavramın araç odaklı yaklaşımlardan kurtarılarak öznenin daha

${ }^{34}$ Jeffrey T. Checkel, "The Constructive Turn in International Relations Theory", World Politics, Cilt 50, Sayı 2, 1998, 324-348, s. 340; Ancak Guzzini, Checkel'in bu argümanına katılmamakta ve eksik olanın öznenin değil, bireyselci bir öznenin teoride kullanılmaması olduğunu iddia etmektedir. Bkz. Stefano Guzzini, "A Reconstruction of Constructivism in International Relations", European Journal of International Relations, Cilt 6, Sayı 2, 2000, 147-182, s. 169.

${ }^{35}$ Checkel, op cit, s. 324-348.

${ }^{36}$ Guzzini, op cit, s. 147-182. 
belirleyici olduğu yaklaşımlara imkân tanımıştır. Burada strateji çalışmalarının içerisinden yapılan eleştirilerin de etkisi olmuştur. Clausewitz' in üzerinde durmuş olduğu her savaşın kendi içerisinde Güvenlik belirsizlik ve iki farklı iradenin var olmasından kaynaklanan bir Stratejileri sürtünmeyi barındırdığı ve stratejik sonucu da yapılan planların değil, savaş alanındaki gerçekliğin belirlediği iddiası, strateji kavramının genişlemesine zemin hazırlamıştır. ${ }^{37}$ Betts de, araçsal ussallık temelli yaklaşımları eleştirerek ve araçsal ussalığın kültürel, siyasi ve psikolojik faktörlerden etkilendiğini belirterek, Simon'un 'bağl1 ussallı" (bounded rationality) kavramı doğrultusunda kararların kültürel bağlamda farklılık ve irrasyonalite gösterebileceğini iddia etmiştir. ${ }^{38}$ Robert Jervis de bilişsel etkenlere dikkat çekerek saf rasyonel bir stratejik düşüncenin mümkün olmadığının altını çizmiştir. ${ }^{39}$

$\mathrm{Bu}$ noktadan yola çıkarak amaçların belirlenmesinde kimlik ve kültürel faktörlerin etkileri incelenmiştir. Özellikle Katzenstein'ın Ulusal Güvenlik Kültürü adlı derleme eserde yer alan makalesinde, kültürden dolayı öznenin tamamen rasyonel ve dolayısıyla stratejik olamayacağını vurgulamıştır. ${ }^{40}$ Bunda öznenin strateji oluşturmasında özneler-arası ve deneyimlerden oluşan yapısal faktörlerin rasyonellikten uzaklaştırdığının altı çizilmiştir. Alexander Wendt' in "Anarşi, Devletlerin Oluşturduğudur" yaklaşımından hareketle, Faruk Yalvaç da "Strateji, Devletlerin Oluşturduğudur" iddiasında bulunmuştur. ${ }^{41}$ Wendt ve Yalvaç

\footnotetext{
${ }^{37}$ Clausewitz, op cit, s. 119-121.

${ }^{38}$ Richard Betts, "Is Strategy an Illusion”, International Security, Cilt 25, Sayı 2, 2000, 5-50.

${ }^{39}$ Robert Jervis, Perceptions and Misperceptions in International Politics, Princeton University Press, Princeton, 1976.

${ }^{40}$ Ronald L. Jepperson, Alexander Wendt ve Peter J. Katzenstein, "Norms, Identity, and Culture in National Security", Peter J. Katzenstein (der.), Culture of National Security: Norms and Identity in World Politics, Columbia University Press, New York, 1996, s. 33-78. ${ }^{41}$ Alexander Wendt, "Anarchy is what States Make of it: The Social Construction of Power Politics", International Organization, Cilt 46, Sayı 2, 1992, 391-425; Faruk Yalvaç, "Strategic Depth or Hegemonic Depth? A Critical Realist Analysis of Turkey's Position in the World System", International Relations, Cilt 26, Sayl 2, 2012, 165-180.
} 
14 yaklaşımlarındaki farklılık, Wendt'in bilimsel gerçekçilik iddiasını

Güvenlik Stratejileri

Y1l: 14

Say1: 27 analizine yansıtamamasında; Yalvaç'ın ise eleştirel gerçekçilik bilim felsefesini analizinde kullanmasında görülmektedir. ${ }^{42}$ Strateji kültürünün nasıl oluştuğuna bakıldığında geçmiş tecrübelerin bir yansıması olduğu ve haliyle geçmişin şimdiyi ve geleceği nasıl şekillendirdiği ile ilgili bir kavram olduğu ortaya çıkmaktadır. ${ }^{43} \mathrm{Bu}$ haliyle stratejik kültür kavramı ait alan yazının da başlangıçta özneyi öncelediği söylenebilir. Kısacası, strateji kavramının ana akım yaklaşımları, akıl ve kültür eksenlerinde ilerlemekte; araçların yanında amaçları da analizlere dâhil etmeye çalışmakta; fakat amaçlar ile araçların diyalektik olarak birbirlerini sürekli olarak nasıl oluşturduğu ve bu sürecin nasıl bir yapıdan etkilendiği konusu tartışılmamaktadır.

\section{Strateji Kavramını Özne/Yapı Diyalektiğine Konumlandırmak}

Kısacası, literatürün kavramın analizine yönelik yaklaşımları üzerine kurulu oldukları bilim felsefesinden dolayı, genellikle sosyal ve öznesel bir kavram olan stratejiyi, kendi sosyal bağlamından kopararak materyalist ve indirgenmiş, tarihsel bağlamından kopararak da tarih dışı, şeyleştirilmiş bir kavram olarak çalışmaktadır. Hâlbuki strateji, özü itibariyle bilinçli öznelerin birlikte var olduğu, ancak diğer taraftan da bu özneleri önceleyen yapıların içinde oluşturulması ve gerçekleştirilmeye çalışılması nedeniyle sosyal; bu yapının sürekli etkileşim ve devinim içerisinde olması nedeniyle tarihsel bir kavramdır. Bu makalenin temel iddiası olan strateji kavramının tarihsel ve sosyolojik bir açıklamasının nasıl yapılacağı ve bunun ne şekilde çalışılması gerektiği sorusuna aradığı cevap çerçevesinde stratejinin özne-yapı diyalektiğine oturtulması gerektiğidir.

${ }^{42}$ Yalvaç, "Strategic Depth or Hegemonic Depth...”, op cit, s. 166.

${ }^{43}$ Alastair Iain Johnston, "Thinking about Strategic Culture", International Security, Cilt 19, Say1 4, 1995, 32-64; Colin S. Gray, "National Style in Strategy", International Security, Cilt 6, Say1 2, 1981, 21-47; Colin S. Gray, "Strategic Culture as Context: The First Generation of Theory Strikes Back", Review of International Studies, Cilt 25, 1999, 46-69; Bill McSweeney, Security, Identity and Interests: A Sociology of International Relations, Cambridge University Press, Cambridge, 1999. 
Strateji kavramı bu makalede en yalın haliyle, araçlar ile amaçların uyumlandırılması olarak tanımlanmıştır. Bu şekilde yapılacak geniş, basit ancak özlü bir tanımlama aslında kavramın çalışılmasında pozitivizmin dayattığı çalışma şekillerinin de ötesine geçmeye imkân tanımaktadır. Güvenlik Stratejileri Stratejinin oluşturulmasında araçlar ile amaçlar arasındaki uyumlandırma süreci de öznenin hedeflediği koşullara ulaşma gayretinden kaynaklanmaktadır. Kısacası amaçsal bir edim olarak özetlenebilecek strateji "hedef koşumlu insani eylem" ${ }^{44}$ olması nedeniyle esasen öznesel, özneye ait bir nitelik taşır. Özne strateji oluşturmaya neden ihtiyaç duymaktadır sorusunun cevabı ve stratejinin belirlenimi süreci, konunun daha geniş bir sosyal bağlama oturtulmasını gerektirmektedir.

Strateji oluşturma ve belirleme temel olarak içinde bulunulan koşulların değiştirilmesi, daha iyilerinin yaratılmasını amaçlamaktadır. Öznenin içinde bulunduğu koşullar onun dışsallığını oluştururken; bu dışsallığın nasıl okunduğu öznenin içselliği ile ilişkilidir. Bunların arasındaki ayrımı pozitivizmin benimsediği şekilde birbirinden tamamen bağımsız birer kategori olarak düşünmekten ziyade, her ikisinin sürekli etkileşim içerisinde olduğu ve etkileşim ve oluşum neticesinde değişime uğradığı bir süreç olarak düşünmek daha doğru olacaktır. Stratejinin amaçsal bir edim olduğu kabul edildiğinde; amacın şekillenmesi ve edimin gerçekleştirilmesi öznenin içselliği ile dışındaki yapının etkileşimi sonucunda gerçekleşmektedir. Özne, içsel olarak karşılaştığ1 çelişkiyi strateji yoluyla dönüştürmeye çalışırken, yapının nesnel dışsallığ 1 ile karşı karşıyadır. $\mathrm{Bu}$ etkileşimin strateji oluşturma aşamasında öznede yarattığı değişim isteği, öznenin bulunduğu koşullardan hoşnut kalmamasından kaynaklanmaktadır. Kısacası strateji, öznenin içinde bulunduğu koşullar veya aktörler ile yaşadığ1 bir "çelişkiyi çözme" (resolving a contradiction) girişimidir. ${ }^{45}$

\footnotetext{
${ }^{44}$ Richard J. Bernstein, Praxis and Action: Contemporary Philosophies of Human Activity, University of Pennsylvania Press, Philedelphia, 1971, s. 43.

${ }^{45}$ Benno Teshcke ve Can Cemgil, "The Dialectic of the Concrete: Reconsidering Dialectic for IR and Foreign Policy Analysis", Millennium: Journal of International Studies, Cilt 11, Say1 5, 2014, 605-635, s. 618.
} 
Çelişkinin varlığı, öznenin algısı ve öznelliğiyle ilgiliyken,

Y11: 14 çelişkinin ortaya çıkışı özne ile yapının etkileşiminin bir sonucudur. Diğer bir ifadeyle, çelişkinin ne olduğu öznesel iken, çelişkiyi doğuran dinamikler daha çok yapısal nitelik taşır. Ancak çelişkinin ortaya çıkmasında öznenin edilgen olduğu düşünülmemelidir. Aksi takdirde, öznenin özne olma niteliklerini ve belirleme gücünü yapının etkenliğine indirgemiş oluruz. Bu nedenle, öznenin diğer öznelerin bulunduğu bir ortamda strateji belirlemesi ve bu belirlenimin öznelerin var olduğu bir yapıda gerçekleşmesi nedeniyle sosyal bir süreçtir. Çelişkinin ve sosyal bir sürecin hâkim olduğu bir ortamda, strateji kavramının diyalektik yöntem ile çalışılması daha doğru bir yaklaşım olacaktır. ${ }^{46}$

Uluslararası ilişkilerde pozitivizmin etkisiyle değişimi araçlardaki değişime indirgeyen anlayışın aksine öznedeki ve yapıdaki değişimin analizine yönelik en önemli araçlardan bir tanesi diyalektik olarak kabul edilmektedir. ${ }^{47}$ Ollman, diyalektik yöntemi "dünyada gerçekleşen bütün değişim ve etkileşimlerle ilgili bir düşünme şekli" "48 olarak kabul eder. Diyalektiğin en önemli unsuru, parçaları "toplumsal oluşum sürecinden" ya da bütünü onu oluşturan parçalardan ayırmayan anlayışııır. ${ }^{49}$ Diyalektik yöntemin özne-yapı etkileşimi çerçevesinde tercih edilmesindeki asıl neden, diyalektik yöntemin de strateji de olduğu gibi çelişkilerin açıklanmasına odaklanmasından kaynaklanmaktadır. Diyalektik, özne eylemini -praxis- bütünsellik içerisinde bağlamsallıştırmakta ve eylemin -strateji- nasıl bir bağlamda şekillendiğini açıklamaya ve analiz etmeye çalışmaktadır. ${ }^{50} \mathrm{Bu}$ bağlamsallıştırmanın

${ }^{46}$ Diyalektik yöntemin, karmaşıklığn hâkim olduğu açı sistem ve süreçlerin analizinde kullanımı için bkz. Hasan Yükselen, "Kompleksite Kuramı ve Diyalektik", Faruk Yalvaç (der.), Tarihsel Materyalizm ve Uluslararast Illişkiler, İmge Yayınevi, Ankara, 2018, s. 333-367.

${ }^{47}$ Faruk Yalvaç, "Uluslararası Tarihsel Sosyoloji: Yapı, Tarih ve Diyalektik", Tayyar Arı (der.), Postmodern Uluslararası İlişkiler Teorileri-2, Dora Yayınları, Bursa, 2014, 305-338, s. 327.

${ }^{48}$ Bertell Ollman, Dance of Dialectics: Steps in Marx's Method, University of Illinois Press, Urbana ve Chicago, 2003.

${ }^{49}$ Heine ve Teschke, op cit, s. 417.

${ }^{50}$ Ibid., s. 415. 
arkasındaki yatan varsayım insanın eyleminin -praxis- geçmişin bir ürünü olan çevresindeki toplumsal bütünlük ile etkileşerek belirlemesi ve belirlenmesidir. ${ }^{51}$ Teshke'nin bu iddias1, Marx'ın belki de en fazla alıntı yapılan, "insanlar kendi tarihini yapar, ancak bunu istedikleri şekilde, kendileri tarafından seçilmiş koşullar altında yapmazlar; var olan koşullar altında yaparlar"s2 cümlesini hatırlatmakta ve öznenin içinde bulunduğu koşullar ile diyalektik etkileşimini çok yalın bir şekilde özetlemektedir.

Bhaskar tarafindan "özgürlük güdüsü”,53 olarak tanımlanan diyalektik, özgürleştirici amaçlar güderken düşünümselliği (reflexivity) davet etmekte ve bu haliyle öznenin içinde bulunduğu şartlar ile olan çelişkisine ve çatışmasına dikkati çekmektedir. Düşünümsellik, öznenin öznelliği ile ilgili bir kavram olup öznenin algısının kendisinde yarattığ düşünce ve güdüler olarak tanımlamak mümkündür. Stratejiyi algılanan bir çelişkiyi çözme girişimi olarak düşündügümüzde strateji düşünceden eyleme evrilen bir süreçtir. Düşünce daha çok bilişsel bir nitelik taşırken, eylem edimsel bir nitelik taşır. Diğer bir ifadeyle, düşünce amaçları şekillendirirken eylem var olan araçların bir türevi şeklindendir. Eyleme dökülmeyen bir düşüncenin stratejinin parçası olup olmayacağı ise düşüncenin hiçbir şekilde boş bir faaliyet olmamasından hareketle ve düşüncenin nesnel gerçekliğin elde edilmesi ve çıar güdümlü -çelişkinin çözümü - olması nedeniyle eylemsizliği ve hareketsizliği seçse de aslında sonuçsaldır. $^{54}$ Zira düşüncenin bizatihi kendisi, "dönüştürücü ve potansiyel olarak yıkıcıdır." ${ }^{, 5}$ Stratejik düşünceler, eylem safhasına geçmese de, farkındalık sonucu algılanan bir çelişkiyi çözmeye yönelik olduğundan aslında dönüştürücü bir faaliyettir. Ancak stratejinin başarısı,

\footnotetext{
${ }^{51}$ Ibid., s. 415; Bütünlük kavramı ile ilgili olarak ayrıca bkz. Faruk Yalvaç, “CR, IR Theory and Marxism", Colin Wight ve Jonathan Joseph (der.), Scientific Realism and International Relations, Palgrave Macmillan, Basingstoke, 2010, s. 167-185.

${ }_{52}^{53}$ Robert C. Tucker, The Marx-Engels Reader, Norton, New York, 1978, s. 595.

${ }^{53}$ Roy Bhaskar, Dialectic: The Pulse of Freedom, Routledge, New York, 2008; Roy Bhaskar, Scientific Realism and Human Emancipation, Verso, Londra, 1986.

${ }^{54}$ Heine ve Teschke, op cit , s. 418.

${ }^{55}$ Ibid.
}

\section{7}

Güvenlik Stratejileri

Y11: 14

Sayı: 27 
öznenin içinde bulunduğu bağlam ve yapı hakkındaki bilgisi ve sahip olduğu araçların amaçlara uyumlandırılması ile doğru orantılıdır.

Y11: 14

$\mathrm{Bu}$ süreçte stratejinin belirlenmesinde içinde bulunulan koşulların öznede yarattığı tezahürün ve algının nasıl şekillendiği, eyleme döküldüğünde "niyet" edilen amaç ile elde edilen sonuç veya "akıbet" arasındaki uyumsuzluğun nereden kaynaklandığının ortaya koyulması noktasında, eleştirel gerçekçiliğin pozitivist yaklaşımlara nazaran daha kapsamlı bir açıklama sunmaya adaydır. Bilimsel gerçekçilik olarak adlandirılan bilim felsefesinin toplum bilimlerine uygulanması olan eleştirel gerçekçilik çerçevesinde ele alınması, stratejiyi ne mümkün kılmaktadır sorusuna açıklama getirirken; pozitivizmin eleştirilen tarihdışı, apolitik, asosyal ve materyalist yaklaşımının aksine kavramın sosyal ve tarihsel bir açıklamasını mümkün kılmaktadır.

Eleştirel gerçekçilik, bilimsel gerçekçiliğin toplum bilimlerine uygulanmış şekli olarak gerçekliğin ontolojik olarak katmanlandırılmıs, yapısal ve farklılaştırılmış ${ }^{56}$ bir doğası olduğunu iddia etmektedir. Pozitivist ve post-modernist yaklaşımların benimsediği "düzlemsel ontoloji" anlayışııın aksine, gerçekliğe "ontolojik derinlik" anlayışı ile yaklaşmaktadır. ${ }^{57} \mathrm{Bu}$ nedenle de "ontolojik gerçekçilik" ${ }^{58}$ olarak da adlandırılmaktadır. Gerçekliğin katmanları; deneyimlediğimiz "görgül

${ }^{56}$ Colin Wight ve Jonathan Joseph (der.), Scientific Realism and International Relations, Palgrave Macmillan, Basingstoke, 2010, s.9-12.

${ }^{57}$ Ontolojik olarak bu farklılı̆ğ olması nedensellik olarak da konuya farklı bir şekilde yaklaşılmasını gerekli kılmaktadır. Düzlemsel ontolojinin nedenselliği David Hume tarafindan ortaya koyulan değişkenlerin doğrudan ve lineer neden-sonuç ilişkileri ile açıklanırken, ontolojik derinlik yaklaşımında nedensellik anlayışı lineer anlayıştan uzaklaşmakta ve neden-sonuç ilişkilerindeki orantılılık kaybolmaktadır. Nedensellik konusunda bkz. Milja Kurki, Causation in International Relations, Cambridge University Press, Cambridge, 2008; Richard Ned Lebow, Constructing Cause in International Relations, Cambridge University Press, Cambridge, 2014; Milja Kurki, "Critical Realism and Causal analysis in International Relations", Millennium: Journal of International Studies, Cilt 35, Say1 2, 2007, 361-378.

58 Faruk Yalvaç, "Eleştirel Gerçekçilik: Uluslararası İlişkiler Kavramında PostPositivizm Sonrası Aşama”, Uluslararası İlişkiler, Cilt 6, Sayı 4, 2010, 3-32, s. 5. 
alan", olayların gerçekleştiği "edimsel alan" ve ortaya çıkarıcı mekanizmaların ve yapıların yer aldığı "gerçek alan" olarak adlandırılmaktadır. ${ }^{59} \mathrm{Bu}$ haliyle eleştirel gerçekçilik, sosyal gerçekliğin açıklanmasında odak noktasını epistemolojiden ontolojiye çevirerek yapısal fakat indirgemeci olmayan bir yaklaşım benimsemektedir. ${ }^{60}$ Daha açı olarak ifade etmek gerekirse, bir kısmını deneyimlediğimiz ve gözlemleyebildiğimiz olayları doğuran daha derinde bizim bilgimizin ötesinde bir gerçekliğin olduğu varsayılmaktadır. $\mathrm{Bu}$ nedenle, bilimin amacı ve görgül düzlemdeki faaliyetlerin sonuçlarının niyetler ile örtüşmesi için öznenin yapılar hakkındaki bilgisinin tam olması gerektiğidir. Aksi takdirde, öznenin eylemleri öznenin bilgisinin ötesinde bulunan yapılarla etkileşimi sonucunda niyet edilmeyen sonuçlar doğurabilmektedir.

Strateji perspektifinden bakıldığında, niyet ile akıbet arasındaki uyumsuzluk öznenin bilgisinin dışındaki yapıların nedensel mekanizmalarından ve ortaya çıkarıcı güçlerinden kaynaklanmaktadır. Bu farkl1lığın temelinde gerçekliğin "geçişli" (transitive) ve "geçişsiz" (intransitive) nesneleri şeklinde yapılan ayrım yatmaktadır. ${ }^{61}$ Öznenin bilgisinin dışında bulunan geçişsiz nesneler ontolojik olarak var olmakta; ancak öznenin bu yapılar ve onların ortaya çıkarıcı nedensel mekanizmaları hakkındaki bilgisi sınırlı kalmaktadır.

Özneyi ve yapıları kendilerine has ontolojik bir analiz kategorisi olarak kabul etmek bunların birbirlerinden bağımsız nedensel mekanizmalarının da olduğunu kabul etmek anlamına gelmektedir. Ancak bu noktada "yapıdan ve özneden ne anlaşılmaktadır" sorularını sormak, tartışmanın odak noktasını ontolojiye çevirmektedir. Ontoloji,

\footnotetext{
${ }^{59}$ Roy Bhaskar, A Realist Theory of Science, Verso, Londra, 1975, s. 13-15.

${ }^{60}$ David Leon, "Reductionism, Emergence and Explanation in International Relations Theory", Colin Wight ve Jonathan Joseph (der.), Scientific Realism and International Relations, s. 31-50.

${ }^{61}$ Roy Bhaskar, A Realist Theory of Science, Verso, Londra, 1975, s. 22. Bhaskar'n "transitive" ve "intransitive" kavramlarını Türkçe'ye "geçișli" ve "geçișsiz" șeklinde kazandıran makale için bkz. Yalvaç, "Eleştirel Gerçekçilik...”, op cit, s. 10.
} 
maddi veya düşünsel niteliklerine bakmadan neyin var olduğu ile ilgilidir. ${ }^{62}$ Neyin var olduğu (ontoloji) ile var olanın bilgisinin elde

Güvenlik Stratejileri

Y1l: 14

Say1: 27 edilmesi (epistemoloji) farkl1 faaliyetler olmakla birlikte, bilimin vazgeçilmez iki unsurudur. Yapılar da ontolojik olarak var olan ancak bilgisinin özne tarafindan tam anlamıyla elde edilemeyen gerçekliklerdir. Yapılar, özneleri önceleyen, önceden var olan, üretilmiş, ancak öznenin eylemlerinden bağımsız ayrı geçeklikleri ve bu nedenle de nedensel mekanizmaları olan varlıklardır. Yapıların öznenin eylemleri üzerindeki etkileri, öznelerin bu yapılar içerisinde bir eyleme girişmeleri sonucunda kendilerini ve nedensel etkilerini ortaya çıkarmaktadır. Bu yapıların tam olarak betimlenmesi ve açıklanması onlar ile karşılaşmadan mümkün görülmemektedir. Yapıların kendilerini ifşa etmeleri, öznenin eylemlerine bağlı olduğundan yapıların "eylem-bağımlı", "zaman/mekân-bağımlı" ve "kavram-bağımlı" oldukları kabul edilmektedir. ${ }^{63}$

Yapıların "eylem-bağımlı" olmaları, nedensel mekanizmalarını ve etkilerini öznenin eyleme geçmesi ile birlikte ortaya çıkardıkları; öznesel bir eylem olmadığında etkilerinin de ortaya çıkmadığından görgül alanda tespitinin de mümkün olmadığını ifade etmektedir. Yapıların etkinliği sadece öznesel etkinlik sonucunda ortaya çıkmakta ve öncesinde tam olarak bilgisine ulaşılamamaktadır. ${ }^{64}$ Bunun nedeni yapıların görünmeyeni de (unobservables) barındırmalarından kaynaklanmaktadır. "Zaman/mekân-bağımlı" olmaları, öznenin eyleme geçtiği mekân ve zamanda yapının farklı etkilerinin olacağını, yeknesak ve doğrusal nedensel güçlerinin olmadığını, bu nedenle de değişkenlik gösterdiğini anlatmaktadır. "Kavram-bağımlı" olmaları ise öznenin yapılar hakkındaki bilgisinin sahip olduğu bilinç, düşünümsellik,

${ }^{62}$ Jonathan Joseph, "Philosophy in International Relations: A Scientific Realist Approach", Millennium: Journal of International Studies, Cilt 35, Sayl 2, 2007, 345-359, s. 354.

${ }^{63}$ Roy Bhaskar, The Possibility of Naturalism: A Philosophical Critique of Contemporary Human Sciences, New York, Harvester Wheatsheaf, 1989, s.38; David Harvey, "Agency and Community: A Critical Realist Paradigm," Journal for the Theory of Social Science, Cilt 32, Sayl 2, 2002, 163-194, s. 170.

${ }^{64}$ Teschke ve Cemgil, op cit, s. 619. 
niyetlilik, farkındalık, bilişsellik ${ }^{65}$ özellikleri ve yetenekleri doğrultusunda tanımlamasına bağımlı olduğunu ifade etmektedir. Yapılan tanımlamalar ve kavramsallaştırmalar içinde bulunulan mekân ve zamanın bir fonksiyonu olan bağlamın öznedeki yansıması olduğundan kavramsallaştırmalar gerek öznenin bilişselliği, gerekse yapının kendisini ifşa etmesi doğrultusunda da değişkenlik gösterdiğinden tarihsel nitelik taşır. $\mathrm{Bu}$ nedenle de, özneyi önceleyen yapıların tarihsel formları hakkında yeterli düzeyde bilgisinin olmasını gerekli kılmaktadır. ${ }^{66}$ Öznenin bilgisinin sınırlılığı çelişkinin ortaya çıktığı andaki mekân ve zamanın koşullarının bir yansıması olduğundan hem sosyal, hem de tarihseldir. Kısacası, yapılar öznel eylemlere ve öznenin bilişsel niteliklerine bağımlıdır. Öznenin kavramsallaştırması da temelde politik bir süreçtir, ${ }^{67}$ çünkü kavramsallaştırma kendiliğinden oluşmamakta, öznenin süreç içerisinde farkındalığı ve öznelliği ile ortaya çıkmaktadır. Kısacası öznellik politik olmanın temelindedir. ${ }^{68} \mathrm{Bu}$ süreçte ne yapı, ne de özne sabit kalmamakta, sürekli bir değişim içerisinde bulunmaktadır. Dolayısıyla ontolojik olarak özne ve yapıyı "olmak" (being) kavramı penceresinden değil de "oluşmak" (becoming) kavramı çerçevesinde irdelemek gereklidir. ${ }^{69} \mathrm{Bu}$ yapılar ontolojik olarak var olsa da, bunların bilgisi ve dolayısıyla stratejik amaçların elde edilmesinde etkileri öznenin yetenekleri ile doğru orantılıdır. Bu nedenle öznelerin bilişselliği yapıların

\footnotetext{
${ }^{65}$ Jonathan Joseph, "Hegemony and the Agent Structure Problem in International Relations: A Scientific Realist Contribution”, Review of International Studies, Cilt 34, 2008, 109-128, s. 117.

${ }^{66}$ Colin Wight, Agents, Structures and International Relations: Politics as Ontology, Cambridge University Press, Cambridge, 2006, s. 5.

${ }^{67}$ R.B.J. Walker, Inside/Outside: International Relations as Political Theory, Cambridge University Press, Cambridge, 1993, s. 128.

${ }^{68}$ Jenny Edkins, Poststructuralism and International Relations: Bringing Political Back In, Lynne Rienner Publishers, Colorado, 1999, s. 7.

69 "Olmak" ve "oluşmak" kavramları hakkında bkz. Emanuel Adler, Communitarian International Relations, Cambridge University Press, Cambridge, 2005, s.32.; Emanuel Adler, "Constructivism and International Relations", Walter Carlsneas, Thomas Risse, ve Beth Simmons (der.), Handbook of International Relations, Routledge, Londra, 2002, 95114; Martin Heidegger, Being and Time, Harper \& Row, New York, 1962.
} 
22

Güvenlik

Stratejileri

Y11: 14

Say1: 27

nedensel güçlerinin deneyimlenmesinde merkezi konumdadır. ${ }^{70}$ Öznenin strateji belirleme ve uygulama sürecinde niyeti ile akıbeti arasındaki uyumsuzluğun kaynağı da, öznenin yapılar hakkındaki bilinç düzeyinin ve durumu algılama yetisinin bir sonucu olarak ortaya çıkmaktadır. ${ }^{71}$

Stratejiye özne-yapı diyalektiğinde düşünceden eyleme bir süreç olarak bakıldığında, farklı ontolojileri olan özne ve yapı, etkileşime girdikleri andan itibaren kendi nedensel mekanizmalarını da devreye sokar. Bu etkileşim esnasında, birbirleriyle karşıt olmaları öznenin mevcut durum ve şartlardan memnun olmamasından kaynaklanmakta ve yapılar kendilerini yeniden üretmeye çalışmaktadır. Dolayısıyla, Bhaskar'ın dediği gibi, toplum hem maddi neden olarak her daim var olan bir koşullar bütünüyken; hem de aynı zamanda insan eylemi sonucunda sürekli yeniden üretilen bir sonucudur. ${ }^{72}$ Yapıların, öznenin eylemleri üzerindeki etkileri mümkün kılma ve sinırlama şeklinde özetlenebilir. Bu nedenle insan eyleminde "zorunluluk" ve "olumsallık" kaçınılmaz olarak bir aradadır. ${ }^{73}$ Yapılar bir yandan özneye öznesel niteliklerinden dolayı eylemde bulunma ve yapıyla olan çelişkilerini çözme imkânı tanısalar da, diğer taraftan da mevcut olan kısıtları yeniden üreterek öznenin öznesel eylemliliğini sınırlayıcı bir etki yaratmaktadır. Kısacası, özne "olasıllığın" peşinde koşarken, yapı "kaçınılmazı" dikte eder. Öznenin sahip olduğu nitelikler -düşünümsellik, farkındalık, bilişsellik- öznenin neyin içinde olduğunun bilgisini oluşturma imkânı verirken; diğer taraftan da farkına vardığı çelişkileri çözme niyetini şekillendirmektedir. Kısacası, strateji oluşturma sürecinde amaçların oluşumu öznenin yapıda ve diğer özneler ile olan çelişkilerinin çözümü stratejik amaçların belirlenmesinde kendisine yer bulmaktadır.

${ }^{70}$ John Scott, "Where is Social Structure?", José Lopez ve Garry Potter (der.), After Postmodernism: An Introduction to Critical Realism, The Athlone Press, Londra, 2001, 77-88, s. 84.

${ }^{71}$ Hasan Yükselen, Turkey's Changing Discourses of Strategy: A Critical Realist Analysis, Doktora Tezi, Orta Doğu Teknik Üniversitesi, Ankara, 2016.

${ }^{72}$ Bhaskar, "The Possibility of Naturalism...", op cit, s. 33-34.

${ }^{73}$ Yalvaç, "Uluslararası Tarihsel Sosyoloji...,", op cit, s. 326. 
Stratejinin belirlenmesi sürecinde düşüncenin eyleme nas1l dönüştügüne bakıldığında, öznenin farkındalığı stratejinin başarısında belirleyici olacaktır. Ancak yapıların önceleyeni ve görünmeyeni barındırmasından dolayı, durumsal farkındalığın bir tezahürü olan düşünce ile bu düşünceye yol açan gelişmeler ve bu gelişmeler arasında tam bir örtüşme bulunmamaktadır. Aksi takdirde, Marx'ın dediği gibi, "şeylerin dış görünüşü ile özü birbirleriyle aynı olsaydı bütün bilim anlamsız olurdu." ${ }^{74}$ Düşünce içinde bulunduğu şartlardan ilham alabilir, etkilenebilir, kısttlanabilir, ancak belirlenmez. Burada önemli olan, gerçeklik ile bu gerçekliğin öznedeki tezahürü ve yansımasıdır. Özne, öznelliğinin bir uzanımı olan bilişselliği (cognition) sayesinde içinde bulunduğu koşulların bir tezahürünü zihninde oluştururken; içinde bulunduğu şartlardan mutlaka etkilenir, ancak bu etkilenme gerçekliğin bire bir resmini oluşturma şeklinden ziyade kendi farkındalığının yüksekliği orantısında bir tezahürdür. Dolayısıyla, gerçeklik ontolojik olarak nesnel olsa da, tezahür bu gerçekliğin bilgisinin oluşturulması olduğundan öznel bir nitelik taşır. Öznenin düşünümselliği, farkındalığı ve bilişselliği sonucunda dışsallığın ve görünenin algılanması ve yorumlanması farklılaşan eylemlerin -praxis- ortaya çıkmasına neden olsa da; görünenin bilgisi gerçekliğin bütününe ve özüne ulaşmanın gerisinde kalacaktır. Kısacası, yapının öznedeki bilgisi "kesinlik" ile değil, "görecelilik" kavramları ile nitelenebilir. ${ }^{75}$

Özne herhangi bir çelişkiyle karşılaştığında, hatta çelişki olarak adlandırma sürecinde bile farkında olsun ya da olmasın içinde bulunduğu yapıdan etkilenir. ${ }^{76}$ Ancak öznel farkındalık yapının kısıtlarından kurtulmanın ilk şartıdır. Bertall Olmann'ın dediği gibi, "zorunluluğun bilgisidir, gerçek özgürlüğün kapılarını açan." veya üretilmiş bilinç ile donanmış özneler içinde bulunulan yapıların ve bunların kısıtlarının yeniden üretiminin ötesine geçemez. Ancak

\footnotetext{
${ }^{74}$ Karl Marx, Capital, Cilt 3, Penguin Books, Harmondsworth, 1981, s. 956.

${ }^{75}$ Heine ve Teschke, op cit, s. 417.

${ }^{76}$ Wyn Jones, op cit, s. 19.

${ }^{77}$ Bertell Olmann, op cit, s. 20.
} 
strateji belirlemedeki amaç var olan yapının ve onun koşullarının farklı

Güvenlik

Stratejileri

Y11: 14

Say1: 27 şekilde üretimi ve dönüştürülmesidir. Pozitivist bilim felsefesi üzerine kurulu olan teoriler belirli bir düşünme ve çözümleme modelini dikte ettiğinden, aslında öznenin öznel niteliklerini bilimsel nesnelliği sağlamak adına çözümlemeden ayırmakta ve neticesinde var olan yapıların yeniden üretilmesini sağlayan ve özneyi her defasında kısıtlayan yanlış bir bilinç üretmekte ve "bilinç yanılsaması"na neden olmaktadır. ${ }^{78}$ Özne ile nesne arasındaki katı ayrım, öznenin nesne tarafindan kontrolünü ve yönlendirilmesini de beraberinde getirmektedir. Kısacası, bilme eylemi özneye ait bir nitelik taşırken, süreçten özneyi kopararak diğer bilgiyi üretme şekillerini de meşru kabul etmemektedir.

Ancak yap1 ve özne ayrı bir ontolojik kategori olarak düşünüldügünde bunların her birinin kendi güçleri olduğu kabul edilmekte ve özneye özne olabilme ve akıbetini tayin etme şans1 tanınmaktadır. Özne karşılaştığ 1 çelişkiyi çözme girişiminde bir eylem içerisine girmekte ve eylemin amaçlarına uygun araçları stratejiye tahsis etmektedir. Ancak stratejinin amaçları ve araçları arasında da diyalektik bir ilişkinin olduğu söylemek mümkündür. Zira stratejinin daha materyal yanı olan araçlar bakımından genişlemesi amaçların belirlenmesinde de kendisini gösterecektir. Pozitivist yaklaşımların aksine, farkındalıktaki değişim de kendisini amaçlarda gösterecek ve stratejinin oluşturulması süreci içerisinde amaçlara koşulabilecek araçların farkına varılmasına da salık verebilecektir. Kısacası, ne amaçlar araçlara, ne de araçlar amaçlara indirgenmemeli; her ikisi aynı bütünsellik içerisinde diyalektik yöntemle incelenmelidir. Zira özne de karşılaştığı bir çelişkiyi çözme girişiminde amaçları ve araçları birlikte düşünmek ve hesaplamak durumundadır. Bu nedenle de, strateji bir "konumlandırılmış faaliyet" (situated acitivity/positioned practice) veya "praxis" olarak değerlendirilmelidir. ${ }^{79}$

${ }^{78}$ Bilincin eylemdeki rolüne yönelik olarak bkz., Richard J.Bernstein, "Conciousness, Existence and Action", Praxis and Action, s. 84-164; Roy Bhakar, "Positivist Illusion", Scientific Realism and Human Emancipation, s. 224-308.

${ }^{79}$ Frederic Merand ve Amelie Forget, "Strategy: Strategizing about Strategy", Rebecca 
Praxis olarak strateji, içinde bulunulan zaman ve mekânda ortaya çıkan bağlam çerçevesinde dişsallığa uyumlanması veya dışsallığın dönüştürülmesi anlamında, daha önce de ifade edildiği gibi, öznenin bilişselliğini, etkileşimini ve gayretini içine alan bir süreçtir. ${ }^{80}$ ve içselliğini dışsallaştırmaktadır." ${ }^{\prime 1}$ Bütün toplumsal pratikler bir yanda eylem boyutunu ve bu pratiğe içkin bir yapısal boyutu içermektedir. ${ }^{82} \mathrm{Bir}$ eylem ve praxis olarak stratejideki nihai amaç, potansiyel olanı gerçeğe dönüştürmektir. ${ }^{83} \mathrm{Bu}$ dönüştürme eylemi bünyesinde değişimi ve geleceği barındırır. Mustafa Kemal Atatürk'ün "geldikleri gibi giderler" sözü de var olan koşulların gelecekte değiştirilmesini amaçlamış ve sonuçta başarılı da olmuştur. Stratejide başarı, öncelikle çelişkinin algılanması ve tanımlanmasına; sonrasında ise eyleme geçilmesine bağlıdır. İlki stratejinin düşünsel boyutunu, ikincisi ise eylemsel -praxisboyutunu ifade etmektedir. Kısacası praxis düşünce ile eylemi birbirine bağlamaktadır. ${ }^{84}$

Tablo 1. Strateji Sürecinde Diyalektik-Praxis İlişkisi

\begin{tabular}{|c|c|}
\hline Düşünce - Diyalektik & Çelişkinin algılanmas1 \\
\hline Eylem - Praxis & Çelişkinin çözülmesi \\
\hline
\end{tabular}

Diyalektikten praxis'e olan süreçte, özne edilgen değil, etkendir. Ancak öznesel etkenlik öznesel niteliklere bağımlı olduğundan öznenin yapısal bağlamı da iyi okuması gerekmektedir. Öznellik ve onun uzanımları olan farkındalık ve düşünümsellik çelişkinin algılanmasını

Adler-Nissen (der.), Bourdieu in International Relations: Rethinking Key Concepts in IR, Routledge, New York, 2013, 93-113, s. 94.

${ }^{80}$ Heine ve Teschke, op cit, s. 413.

${ }^{81}$ Pieree Bourdiue, Outline of a Theory of Practice, Cambridge University Press, Cambridge, 1977, s. 205.

${ }^{82}$ Wight, op cit, s.47; Robert Cox, op cit, , s. 129-130.

${ }^{83}$ Heine ve Teschke, op cit, s. 414.

${ }^{84}$ Teschke ve Cemgil, op cit, s. 616. 

çözümünü sağlamaktadır. Stratejinin "düşünceden eyleme" olan süreç olması da buradan kaynaklanmaktadır. Marx'ın "fillozoflar sadece çeşitli şekillerde dünyayı yorumladılar, fakat maksat, onu değiştirmek" diyerek stratejinin düşüncenin ötesinde eyleme geçirilmesi gerekliliğini de ortaya koymuştur.

Strateji bir praxis olarak özne tarafindan nasıl oluşturulmaktadır sorusuna stratejinin "durumsal", "konumsal" ve "araçsal" üç unsuru ile cevap verilebilir. ${ }^{86}$ Stratejinin "durumsal" unsuru, öznenin strateji oluştururken her şeyden önce içinde bulunduğu koşulları ve durumu algılamasına ve çelişkinin ne olduğunu algılamasını ifade etmektedir. İçinde bulunulan koşulların doğru şekilde okunması, yukarıda bahsedildiği gibi, doğru stratejilerin oluşturulması için ön koşuldur. Karşı karşıya bulunduğu çelişkilerin ne olduğunun farkına varmadan onların çözümü de olanaksızdır. Bu nedenle, içinde bulunulan mekânzamansal bağlamda yapının ne gibi etkiler ortaya çıkarabileceğinin mümkün olan en açık şekilde ortaya koyulması gerekmektedir. Yapısal bağlamın ortaya çıkardığı çelişkinin gerçekten özneye yönelik bir sınama olması gerekmektedir. Bu noktada da pozitivizmin "araçsal ussalı̆̆ı"ndan ziyade "varlıksal ussallık" ön plana çıkmakta ve öznenin nesnelleştirildiği üretilen ussallıktan ziyade öznenin özne olma yetisini devam ettirdiği bir ussallık anlayışına olanak vermektedir.

${ }^{85}$ Tucker, op cit, s. 143.

${ }^{86}$ Merand ve Forget, op cit, s. 98. Merand ve Forget'in stratejinin durumsal, konumsal ve araçsal unsurlarını Clausewitz'in Kuvvet-Zaman-Mekân üçlemesi üzerine kurmuş olduğu değerlendirilmekle birlikte, Merand ve Froget'in kavramlara, Clausewitz'in kavramları ile karşılaştınldığında, daha öznel ve öznesel bir anlam verdiği söylenebilir. Zira kuvvetmekân-zaman kavramları daha nesnel durmaktadır. Clausewitz'in bu kavramsal üçlemeyi kuvvetin sıklet merkezi oluşturmak amaciyla belirlenen mekân ve zamanda birleşmesi ile ilgili olarak kullanmıştır. Clausewitz, kuvvet-mekân-zaman üçlemesini kuvvetten yana kullanarak ve belirlenen mekân ve zamanda kuvvet yoğunluğunu sağlamaya odaklanarak aslında mekân ve zaman faktörlerini de kuvvete indirgemiştir. Diğer bir ifadeyle, mekân ve zamanın kuvvet faktörünün etkisini artırmak için nasıl kullanılması gerektiğini anlatmıştır. Bkz. Clausewitz, op cit, 204-209. 
Özneyi devlet olarak ele aldığımızda; devleti önceleyen ve davranışlarını etkileyen ilk bakışta üç yapıdan bahsetmek mümkündür. Bunları "uluslararası siyasal sistem", "küresel ekonomik sistem" ve "coğrafya" şeklinde siralamak mümkündür. Bunlardan birincisi, amaçlara yön verirken; ikincisi araçlara yön vermekte; coğrafya ise stratejinin uygulandığ1 mekânsal boyutunu oluşturmaktadır. Bunlardan her biri, öznenin çelişki ile karşılaşması ve anlamlandırması noktasında kendi zamansal etkilerini farklı şekilde doğururken; aynı zamanda daha uzun erimli tarihsel süreklilikleri de barındıran stratejik düşüncenin oluştuğu ana etkilerini taşıyacaktır.

"Uluslararası siyasal sistem", bir yandan özne olarak devletin içinde hareket ettiği bir bağlam olarak kendine has dönemsel etkileri ve özellikleri ile öznede çelişkileri doğururken; diğer yandan da siyasal sistemin o dönemdeki dinamikleri öznenin amaçlarını şekillendirmektedir. Özne için önemli olan, öznesel nitelikleri vasitasılyla onun varlığını yeniden üretmeye veya dönüştürmeye yönelik olarak farkında olması ve amaçlarını bu farkındalık, düşünümsellik ve bilişsellik yoluyla belirlemesi olacaktır. Uluslararası siyasal sistemdeki değişimler daha yavaş, ancak etkileri bakımından da bir o kadar kuvvetli olarak kendisini göstermektedir. Örneğin Fransız İhtilali veya sanayileşmenin bir yandan milliyetçilik gibi akımları ortaya çıkararak temel siyasal örgütlenme biçimini imparatorluklardan ulus devletlere dönüştürmesi çelişkisini, diğer yandan da strateji oluşturma süreci üzerindeki etkilerini doğurmuştur. Günümüzde ise küreselleşmeyle birlikte artan, dağıtık, derin ve süratlenen bir hal alan iletişimin yarattı̆̆ birey bazındaki bağlantıların yarattığı çelişkilere mevcut siyasal örgütlenme biçimlerini tehdit etmesi sayılabilir. ${ }^{87}$ Ancak yapısal değişimler ve bu değişimlerin yarattığı çelişkiler, kendilerini özneye eylem-bağımlı olmalarından dolayı çok açık bir şekilde ifşa etmeyeceğinden, strateji oluşturma sürecinde öznede yarattığı tezahür de farklı şekillerde olabilecektir.

\footnotetext{
${ }^{87}$ James Rosenau, Turbulence in World Politics: A Theory of Change and Continuity, Princeton University Press, Princeton, 1990; Parag Khanna, Connectography: Mapping the Future of Global Civilization, Random House, New York, 2016.
} 
28

Güvenlik

Stratejileri

Y11: 14

Say1: 27

"Küresel ekonomik sistem" de siyasal yap1 gibi kendine has özelliklerini ve nedensel mekanizmalarını farklı şekilde ifşsa edecektir. Stratejinin araçlar boyutu üzerinde materyal etkileri olduğundan, küresel ekonomik sistemdeki değişimler öznenin amaçlarına koşabileceği araçları da içinde bulunulan zaman-mekânsal bağlamın özelliklerine göre değiştirebilecektir. Bu nedenle, özne olarak devletin ekonomik yapıdan amaçlar için devşirebileceği veya devşirmek istediği araçlar öznenin amaçları üzerinde etkisi olduğu gibi, araçların da amaçlar üzerinde etkisi olacağından, aslında birbirleri arasında diyalektik bir ilişki vardır. Ancak burada stratejinin daha çok materyal yönü ön plana çıktığından, öznenin belirlediği strateji çerçevesinde düşünsel araçlar da stratejinin amaçlarına koşulabilir. Örneğin Türkiye'nin 2002-2011 döneminde Orta Doğu'da dış politika stratejisini sert güç yerine yumuşak güç üzerine kurmas1 gösterilebilir. Ancak siyasal sistemdeki diğer aktörlerin stratejileri mevcut yapıyı "reelpolitik" anlamda yeniden üreterek yumuşak gücü ilgisiz kılmaları neticesinde, koşulan stratejinin araçlardan yoksun amaçlar olarak karşımıza çıkmasına neden olmuştur.

Son olarak "coğrafya", stratejinin uygulandığı mekânı temsil etmektedir. Mekân da nedensel güçlerini farklı bağlamlarda ve zamanlarda farklı şekillerde ifşa edeceğinden, strateji üzerinde doğrudan fakat öngörülemeyen etkisi vardır. Yapısal olarak Osmanlı'nın son dönemlerinden itibaren uygulamış olduğu güçler dengesi stratejisi, Orta Doğu'da farklı aktörlerin stratejik amaçlarından kaynaklanan çatışma hali bir süreklilik göstermekte, ancak bu süreklilik etkilerini farklı şekillerde gösterebilmektedir.

Stratejinin "konumsal" boyutuna baktığımızda, öznenin yapısal bağlamı ne şekilde okuduğu ve ortaya çıkan çelişkiye yönelik kendisini ne şekilde konumlandırdığı ön plana çıkmaktadır. Diğer bir ifadeyle, çelişkinin ne şekilde çözümlenmesi gerektiği konusunda nasıl bir strateji belirleyeceği stratejinin konumsal boyutuna karşılık gelmektedir. Burada durumdan konuma ilerleyen bir süreç oluşmakta; durumsallıkta öznenin bilişselliği ön plandayken, konumlanırken eylemselliği ön plana çıkmaya başlamaktadır. Çünkü artık çelişki özne tarafindan algılanmış ve öznesel olarak çözümlenme aşamasına gelmeye başlamıştır. Bu süreçte özne stratejik amacını belirlemeye ve bu amaç 
doğrultusunda eyleme geçmeye başlayacaktır. Ancak stratejinin ve öznesel konumlandırmanın başarısı amacın öznesel olmasına bağımlıdır. $\mathrm{Bu}$ nedenle, "amacın belirlenmesinde öznellik yoksa amacın Güvenlik gerçekleştirilmesinde de olmayacaktır." ${ }^{88}$ Öznenin çelişki karşısında Stratejileri kendisini ne şekilde konumlandırdığı, çelişkinin hangi kaynaktan türediğine göre değişiklik gösterecek ve bu da stratejinin doğasını değiştirecektir. Çelişkinin ortaya çıkışı, yapıdan kaynaklanabildiği gibi, diğer öznelerin ortaya koyduğu stratejilerden de kaynaklanabilir.

Özne ve yapı kaynaklı çelişkilere yönelik stratejiler de çelişkinin kaynağına göre "tehdit-odaklı" ve "vizyon-odaklı" olarak sinıflandırılabilir. Burada yapılan sinıflandırma kesin sinırlar ile çizilmiş bir sınıflandırmadan ziyade, kök nedene yönelik bir sinıflandırma olup gerek "vizyon-odaklı", gerekse "tehdit-odaklı" stratejilerin hem yapısal, hem de öznesel nedenleri olabilecektir. Tehdit-odaklı stratejiler daha çok diğer aktörlerin ve öznelerin yarattığı çelişkilerden kaynaklanmakla birlikte, diğer aktörleri bu yöne iten yapısal faktörleri de göz ardı etmemek gerekir. Vizyon-odaklı stratejiler ise, öznenin içinde bulunduğu koşulları değiştirmesine yönelik olarak oluşturulan ve daha çok gelecekte oluşturulacak stratejilere daha uygun bir ortam yaratmak adına oluşturulmaktadır.

Son olarak, stratejinin "araçsal" unsuru, stratejinin doğrudan araçlarına tekabül etmekle birlikte sadece materyal araçlara indirgenmemelidir. Her ne kadar materyal araçlar stratejinin önemli ve vazgeçilmez bir boyutu olsa da, düşünsel araçlar da stratejik araç olarak kullanılabilir. Özellikle, yumuşak güç tartışmalarını bu kapsamda değerlendirmek daha doğru olacaktır. Zira güç kavramı üzerine yapılan tartışmalarda hem yumuşak gücün, hem de sert gücün birlikte kullanıldığı "akıllı güç" gibi yeni kavramsallaştırmalar kendisine yer edinmektedir. ${ }^{89}$ Stratejinin araçsal unsuru ile ilgili olarak üzerinde durulması gereken bir diğer nokta da, araçların mevcut ve potansiyel

\footnotetext{
${ }^{88}$ Joseph, op cit, s. 152.

${ }^{89}$ Joseph S. Nye, The Future of Power, Public Affairs, New York, 2011.
} 

girişildikten sonra kendisini süreç içerisinde ortaya çıkaran ve özne tarafından amaca koşulabilecek olana karşılık gelmektedir. Özneler, bu konuda daha çok mevcut olan araçlar üzerinden strateji üretme gayreti içerisinde olmayı olası hataları önlemek adına tercih edebilmektedir. Fakat öznesel farkındalığın olduğu durumlarda eylemin kendi enerjisini üretebileceği stratejiler de olasilık dâhilindedir.

\section{Sonuç}

$\mathrm{Bu}$ makalede, stratejinin öznesel bir kavram olmasindan yola çıkılarak, içerisinde bulunduğu yapısal koşullar ile olan çelişkisini çözme girişimi olduğu savunulmuştur. Kavram, pozitivizmin egemenliği altında olan geleneksel ana akım teoriler çerçevesinde analiz edildiğinde, kaçınılmaz olarak indirgemecilik ile karşı karşıya kalmaktadır. Bunun nedeni, ölçülebilir olarak karşımızda sadece araçların maddi şekillerinin kalmasından kaynaklanmaktadır. Hâlbuki amaçlar mı araçları, yoksa araçlar mı amaçları belirlemektedir şeklindeki bir soruya verilecek cevap da, ikisinin de tek başına yeterli olamayacağıdır. Çünkü amaçlar ve araçlar arasında diyalektik bir ilişki mevcuttur. Özne düşünümselliği ve farkındalığı sayesinde karşılaştığı bir çelişkiyi çözme yolunda birtakım amaçlar benimseyecektir. Ancak bu amaçlar da tek başına stratejinin belirlenmesinde yeterli olmayacak, belirlenen amaçlara koşulabilecek araçları da belirleme ihtiyacı duyacaktır. Burada özne amaçları belirlerken, içerisinde bulunduğu durumu okuması neticesinde kendisini konumlandıracak ve mevcut ve muhtemel araçları da dikkate alacaktır. Görüldüğ̈ gibi, strateji, özne için hiçbir zaman tek başına amaçların ya da araçların yönlendirdiği bir süreç niteliğini taşımayacak; aksine her zaman araçların ve amaçların bir bütün olarak içerisinde bulunulan ortamda belirlendiği diyalektik ve birbirine indirgenemeyen bir süreç olacaktır. Bu nedenle, sadece araçların ön planda tutulduğu bir strateji anlayışından ziyade, diğer bilinçli aktörlerin ve içerisinde bulunulan yapıların sürekli ve değişken etkileşimlerini içeren tarihsel ve sosyolojik bir strateji anlayışı stratejinin düşünceden eyleme nasıl evrildiğini açılamada daha bütünsel bir yaklaşım sunacaktır. Bu şekildeki bir yaklaşım özellikle, eleştirel gerçekçilik bakış açısının hâkim olduğu bir özne-yap1 diyalektiği öznenin niyeti ile akıbeti arasındaki farkın 
nereden kaynakladığını da açıklamaktadır. Kısacası, strateji bir kavram

olarak geleneksel ve pozitivist yaklaşımla çalışılmayacak kadar çok boyutlu, dinamik, sosyal ve diyalektik bir kavramdır.

\section{Summary}

The question posed in this article can be simply defined "as what makes strategy?" Different from the existing literature which tends to provide ahistorical and asociological explanations, the article suggests changing meta-theoretical stance that incorporates critical realism to explanation and seeks explanation within dialectical understanding of agent-structure debate. The first part of the article, subtitled as "Questioning the Study of the Concept of Strategy: The Concept, Approach and the Critique," critically explores how existing literature approaches to the concept in order to reveal missing parts of the strategy. Particularly, how reductionism and reification dominated the study of the concept is explored in this section. The second part, subtitled as "Situating the Concept of Strategy within Agent-Structure Dialectic," suggests a model, which is built upon the attempt to overcome reified and reduced study of the concept in the way of articulating a model that proved the opportunity to make a historical and sociological analysis of the concept.

The concept of strategy, which though originated in military domain and focused on the study of art of war, has, in time, expanded and infiltrated into other disciplines, particularly, on the study of the decisions that have wider vital implications. Within the discipline of International Relations, similar pattern was observed which brought about the broadening and deepening of its study as in the case of the concept of security. Broadening the study of the concept of strategy brought about introduction of differing and contending critiques, thanks to discussion within broader theoretical contexts. Despite this broadening has provided new perspectives in its study, unfortunately, they could not overcome reification the constituent parts, either ends or means, and eventual reduction of the concept to the study of means. One of the basic reasons of this tendency is the prominence or dominance

Güvenlik Stratejileri

Y11: 14

Say1: 27 
of positivist meta-theoretical stance in handling the strategy. The imminent outcome of this tendency, based on reification and reduction,

Güvenlik Stratejileri

Y11: 14

Sayı: 27 is the removal of social aspect from the study of the concept strategy, which, on the contrary, should be treated as a sociological phenomenon. In fact, de-socialization of strategy was accompanied by de-historization, which disconnected the study of the concept from its historical context, which with its respective features determines the nature of strategy. The inevitable outcome of this tendency was the detachment of agency as the social element of strategizing from the process. In a way, through dominant approaches, agency got disconnected from its structure leading the study of structural distribution of powers, and hence, agential subjectivity got objectified.

Strategy, as an attempt to alter the unwanted, unpleased conditions of the context, or as an attempt to create more favorable conditions to formulate more emancipatory strategies in future, basically, is a goal directed activity to "resolve a contradiction". Perception of contradiction is the outcome of agency's dialectical interaction with the structure, which inherently pleaded with enabling and constraining forces. In that sense, strategy, conceived as a "process" from "thought to praxis", is a phenomenon dedicated to change a potentiality into actuality. However, agency without its distinctive features such as subjectivity, reflexivity, consciousness, has the pulse to perceive the contradiction and capability through allocating means to the get intended outcomes. However, "what is intended" cannot be observed in "what is actualized", due to the generative mechanisms and forces of structures that are beyond the awareness, consciousness, and hence, conception of agency.

Structures by being "concept-", "activity-", and "spacio-temporaldependent" on agency, produce differing generative forces in different contexts. This difference is explained through the concept of "ontological depth" of critical realism, which suggests that the reality has stratified, differentiated, and structured nature. The existence of reality beyond the observation of subjects leads to the acceptance of unobservable but real generative causal mechanisms that are capable to alter what is intended by agency. The three main structures that have causal generative forces on agency are "international political system", 
"global economic system", and "geography". These three structures, in which agency operates, are embedded with the forces to alter acts of agency, which also have somehow dialectical relationship between themselves and with agency as well.

Consequently, strategy as an agential act that comprises a process as "positioned practice" or "situated activity". Agency produces its "praxis", through the dialectical interaction with the abovementioned structures by employing "situational", "positional" and "dispositional" elements of strategizing. In conclusion, in this article, a new model for the study of strategy is suggested that eliminates the danger of reduction of strategy to "means" by reifying "ends".

\section{Kaynakça}

Kitaplar

ADLER, Emanuel, Communitarian International Relations, Cambridge University Press, Cambridge, 2005.

BAUFRE, André, An Introduction to Strategy: With Particular Reference to the Problems of Defence, Politics, Economics, and Diplomacy in the Nuclear Age, Faber \& Faber, Londra, 1965.

BAYLIS, John, James J. Wirtz ve Colin S. Gray, Strategy in the Contemporary World, 5'inci Basım, Oxford University Press, Oxford, 2016. BERNSTEIN, Richard J., Praxis and Action: Contemporary Philosophies of Human Activity, University of Pennsylvania Press, Philedelphia, 1971.

BHASKAR, Roy, A Realist Theory of Science, Verso, Londra, 1975. BHASKAR, Roy, Scientific Realism and Human Emancipation, Verso, Londra, 1986.

BHASKAR, Roy, The Possibility of Naturalism: A Philosophical Critique of Contemporary Human Sciences, Harvester Wheatsheaf, New York, 1989. 
BHASKAR, Roy, Dialectic: The Pulse of Freedom, Routledge, New York, 2008.

Güvenlik

Stratejileri

Y1l: 14

Say1: 27

BOOTH, Ken, Theory of World Security, Cambridge University Press, Cambridge, 2007.

BOURDIUE, Pieree, Outline of a Theory of Practice, Cambridge University Press, Cambridge, 1977.

BRODIE, Bernard, War and Politics, Cassell, Londra, 1974.

BUZAN, Barry, People, States and Fear: An Agenda for International Security Studies in the Post-Cold War Era, ECPR, Colchester, 2007.

BUZAN, Barry, Ole Weaver ve Jaap de Wilde, Security: A New Framework for Analysis, Lynne Rienner, Boulder, 1998.

CLAUSEWITZ, Carl Von, On War, (çev.Michael Howard ve Peter Paret), Princeton University Press, Princeton, 1976.

EDKINS, Jenny, Poststructuralism and International Relations: Bringing Political Back In, Lynne Rienner Publishers, Colorado, 1999. FOUCAULT, Michel, The History of Sexuality: The Will to Knowledge, Penguin, London, 1998.

FOUCAULT, Michel, The Archeology of Knowledge, Routledge, Oxon, 2008.

GRAY, Colin S., Modern Strategy, Oxford University Press, Oxford, 1999. GRAY, Colin S., The Future of Strategy, Polity Press, Cambridge, 2015. HEIDEGGER, Martin, Being and Time, Harper \& Row, New York, 1962.

HEUSER, Beatrice, The Evolution of Strategy: Thinking War from Antiquity to the Present, Cambridge University Press, Cambridge, 2010. JERVIS, Robert, Perceptions and Misperceptions in International Politics, Princeton University Press, Princeton, 1976.

KATZENSTEIN, Peter (der.), Culture of National Security: Norms and Identity in World Politics, Columbia University Press, New York, 1996. KHANNA, Parag, Connectography: Mapping the Future of Global Civilization, Random House, New York, 2016.

KEOHANE, Robert O. ve Joseph S. NYE, Power and Interdependence: World Politics in Transition, Little \&Brown, Boston, 1989.

KURKI, Milja, Causation in International Relations, Cambridge University Press, Cambridge, 2008. 
LEBOW, Richard Ned, Constructing Cause in International

Relations, Cambridge University Press, Cambridge, 2014.

LIDDELL Hart, Basil, Strategy, Faber, Londra, 1967.

MARX, Karl, Capital, Cilt 3, Penguin Books, Harmondsworth, 1981.

Güvenlik

Stratejileri

MCSWEENEY, Bill, Security, Identity and Interests: A Sociology of

International Relations, Cambridge University Press, Cambridge, 1999.

NYE, Joseph S., The Future of Power, Public Affairs, New York, 2011.

OLLMAN, Bertell, Dance of Dialectics: Steps in Marx's Method,

University of Illinois Press, Urbana ve Chicago, 2003.

PARET, Peter, Gordon A. Craig and Felix Gilbert, Makers of Modern

Strategy: From Machiavelli to the Nuclear Age, Princeton University Press, Princeton, 1986.

REISS, H.S. (ed.), Kant: Political Writings, Cambridge University Press, Cambridge, 1991.

ROSECRANCE, Richard ve Arthur A. Stein, The Domestic Bases of Grand Strategy, Cornell University Press, Ithaca ve Londra, 1993.

ROSENAU, James, Turbulence in World Politics: A Theory of Change and Continuity, Princeton University Press, Princeton, 1990. ROUSSEAU, David L., Democracy and War: Institutions, Norms, and the Evolution of International Conflict, Stanford University Press, Stanford, 2005.

THUCYDIDES, The Landmark Thucydides: A Comprehensive Guide to "The Peloponnesian War", Robert B. Strassler (der.), Richard Crawley (çev), The Free Press, New York, 1996.

TUCKER, Robert C., The Marx-Engels Reader, Norton, New York, 1978.

WALKER, R.B.J., Inside/Outside: International Relations as Political Theory, Cambridge University Press, Cambridge, 1993.

WALTZ, Kenneth, Theory of International Politics, Addison-Wesley Publishing Company, Reading, 1979.

WIGHT, Colin, Agents, Structures and International Relations: Politics as Ontology, Cambridge University Press, Cambridge, 2006.

WIGHT, Colin ve Jonathan Joseph (der.), Scientific Realism and International Relations, Palgrave Macmillan, Basingstoke, 2010.

WYN JONES, Richard, Security, Strategy and Critical Theory, Lynne Rienner, Colorado, 1999. 


\section{Makaleler ve Kitap Bölümleri}

Güvenlik

Stratejileri

Y1l: 14

Say1: 27
ADLER, Emanuel, "Constructivism and International Relations", Walter Carlsneas, Thomas Risse, ve Beth Simmons (der.), Handbook of International Relations, Routledge, Londra, 2002, 95-114.

ASHLEY, Richard K. ve R.B.J. Walker, "Speaking the Languages of Exile: Dissident Thought in International Studies", International Studies Quarterly, Cilt 34, Say1 3, 1990, 259-268.

BETTS, Richard, "Is Strategy an Illusion", International Security, Cilt 25, Say1 2, 2000, 5-50.

BRODIE, Bernard, "Strategy as a Science", World Politics, Cilt 1, Say1 4, July 1949, 467-88.

CHECKEL, Jeffrey T., "The Constructive Turn in International Relations Theory", World Politics, Cilt 50, Say1 2, 1998, 324-348.

COX, Robert, "Social Forces, States and World Orders: Beyond International Relations Theory," Millennium: Journal of International Studies, Cilt 10, Say1 2, s.126-155.

COZETTE, Muriell, "Realistic Realism?: American Political Realism, Clausewitz and Raymond Aron on the Problem of Means and Ends in International Politics", Journal of Strategic Studies, Cilt 27, Say1 3, 2010, 423-458.

DOYLE, Michael W., "Kant, Liberal Legacies, and Foreign Affairs, Part 1 \&2," Philosophy \& Public Affairs, Cilt 12, Say1 3, 1983, 205-35.

FINNEMORE, Martha ve Kathyrn Sikkink, "International Norm Dynamics and Political Change", International Organization, Cilt 52, Say1 2, 1998, 887-917.

FOSTER, Gregory, "Research, Writing and the Mind of the Strategist", Joint Force Quarterly, Say1 14, 1996, 111-115.

GRAY, Colin S., "National Style in Strategy", International Security, Cilt 6, Sayı 2, 1981, 21-47;

GRAY, Colin S., "Strategic Culture as Context: The First Generation of Theory Strikes Back", Review of International Studies, Cilt 25, 1999, 49-69.

GUZZINI, Stefano, "A Reconstruction of Constructivism in International Relations”, European Journal of International Relations, Cilt 6, Say1 2, 2000, 147-182. 
HAGAN, Joe D., "Domestic Political Systems and War Proneness", Mershon International Studies Review, Cilt 38, 1994, 183-207. HARVEY, David, "Agency and Community: A Critical Realist Güvenlik Paradigm," Journal for the Theory of Social Science, Cilt 32, Say1 2, Stratejileri 2002, 163-194.

HEINE, Christian ve Benno TESCHKE, "Sleeping Beauty and Dialectical Awakening: On the Potential of Dialectic for International Relations", Millennium: Journal of International Studies, Cilt 25, Say1 2, 1996, 399-423.

JOHNSTON, Alastair Iain, "Thinking about Strategic Culture", International Security, Cilt 19, Say1 4, 1995, 32-64.

JOSEPH, Jonathan, "Foucault and Reality", Capital \& Class, Cilt 82, 2004, 141-163.

JOSEPH, Jonathan, "Philosophy in International Relations: A Scientific Realist Approach", Millennium, Cilt 35, Say1 2, 2007, 345-359.

JOSEPH, Jonathan, "Hegemony and the Agent Structure Problem in International Relations: A Scientific Realist Contribution", Review of International Studies, Cilt 34, Say1 1, 2008, 109-128.

KURKI, Milja, "Critical Realism and Causal analysis in International Relations", Millennium: Journal of International Studies, Cilt 35, Say1 2, 2007, 361-378.

LEON, David, "Reductionism, Emergence and Explanation in International Relations Theory," Colin Wight ve Jonathan Joseph (der.), Scientific Realism and International Relations, Palgrave Macmillan, Basingstoke, 2010, 31-50.

MERAND, Frederic ve Amelie Forget, "Strategy: Strategizing about Strategy", Rebecca Adler-Nissen (der.), Bourdieu in International Relations: Rethinking Key Concepts in IR, Routledge, New York, 2013, 93-113.

MURRAY, Williamson ve Mark Grimsley, "Introduction: On Strategy", Williamson Murray, MacGregor Knox ve Alvin Bernstein (der.) The Making of Strategy: Rulers, States, and War, Cambridge University Press, Cambridge, 1994, 1-24. 
SCOTT, John, "Where is Social Structure?", José Lopez ve Garry Potter (der.), After Postmodernism: An Introduction to Critical Realism, The Athlone Press, Londra, 2001, 77-88.

Y11: 14 TESHCKE, Benno ve Can Cemgil, "The Dialectic of the Concrete: Reconsidering Dialectic for IR and Foreign Policy Analysis", Millennium: Journal of International Studies, Cilt 11, Say1 5, 2014, 605-635.

WALT, Stephen, "Renaissance of Security Studies", International Studies Quarterly, Cilt 35, Say1 2, 1991, 211-239.

WENDT, Alexander, "Anarchy is what States Make of it: The Social Construction of Power Politics", International Organization, Cilt 46, Say1 2, 1992, 391-425.

WINDSOR, Philip, "The Clock, the Context and Clausewitz", Millennium: Journal of International Studies, Say1 6, Cilt 2, 190-196.

YALVAÇ, Faruk, "CR, IR Theory and Marxism", Colin Wight ve Jonathan Joseph (der.), Scientific Realism and International Relations, Palgrave Macmillan, Basingstoke, 2010, 167-185.

YALVAÇ, Faruk, "Eleştirel Gerçekçilik: Uluslararası İlişkiler Kavramında Post-Positivizm Sonrası Aşama." Uluslararası İlişkiler, Cilt 6, Say1 4, 2010, 3-32.

YALVAÇ, Faruk, "Strategic Depth or Hegemonic Depth? A Critical Realist Analysis of Turkey's Position in the World System", International Relations, Cilt 26, Say1 2, 2012, 165-180.

YALVAÇ, Faruk, "Uluslararası Tarihsel Sosyoloji: Yap1, Tarih ve Diyalektik", Tayyar Arı (der.), Postmodern Uluslararası İlişkiler Teorileri-2, Dora Yayınları, Bursa, 2014, 305-338.

YÜKSELEN, Hasan, "Kompleksite Kuramı ve Diyalektik", Faruk Yalvaç (der.), Tarihsel Materyalizm ve Uluslararası İlişkiler, İmge Yayınevi, Ankara, 333-367.

Tezler

YÜKSELEN, Hasan, Turkey's Changing Discourses of Strategy: A Critical Realist Analysis, Doktora Tezi, Orta Doğu Teknik Üniversitesi, Ankara, 2016. 
